\title{
Application Of Computer-Based Technology To The Teaching Of Writing In Spanish As A Foreign Language: A Case Study
}

\author{
Nuria Gago \\ West Virginia University
}

Follow this and additional works at: https://researchrepository.wvu.edu/etd

Part of the Educational Technology Commons, International and Comparative Education Commons, and the Spanish Linguistics Commons

\section{Recommended Citation}

Gago, Nuria, "Application Of Computer-Based Technology To The Teaching Of Writing In Spanish As A Foreign Language: A Case Study" (2000). Graduate Theses, Dissertations, and Problem Reports. 10151. https://researchrepository.wvu.edu/etd/10151

This Thesis is protected by copyright and/or related rights. It has been brought to you by the The Research Repository @ WVU with permission from the rights-holder(s). You are free to use this Thesis in any way that is permitted by the copyright and related rights legislation that applies to your use. For other uses you must obtain permission from the rights-holder(s) directly, unless additional rights are indicated by a Creative Commons license in the record and/ or on the work itself. This Thesis has been accepted for inclusion in WVU Graduate Theses, Dissertations, and Problem Reports collection by an authorized administrator of The Research Repository @ WVU. For more information, please contact researchrepository@mail.wvu.edu. 


\title{
APPLICATION OF COMPUTER-BASED TECHNOLOGY TO THE TEACHING OF WRITING IN SPANISH AS A FOREIGN LANGUAGE: A CASE STUDY
}

\author{
By \\ Nuria Gago \\ A Thesis submitted to the \\ Eberly College of Arts and Sciences \\ At West Virginia University \\ in partial fulfillment of the requirements \\ for the degree of \\ Master of Arts \\ in Foreign Languages \\ Dara Shaw \\ Frank Medley, Jr., Ph. D. \\ María Amores, Ph.D. Chair \\ Department of Foreign Languages \\ Morgantown, West Virginia \\ 2000
}


UMI Number: 1402829

\section{Copyright 1999 by}

Gago, Nuria

All rights reserved

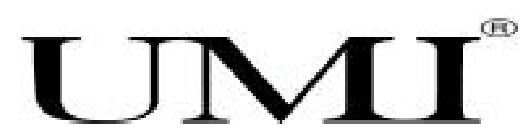

UMI Microform 1402829

Copyright 2000 by Bell \& Howell Information and Learning Company.

All rights reserved. This microform edition is protected against unauthorized copying under Title 17, United States Code.

Bell \& Howell Information and Learning Company 300 North Zeeb Road

P.O. Box 1346

Ann Arbor, MI 48106-1346 



\title{
ABSTRACT \\ APPLICATION OF COMPUTER-BASED TECHNOLOGY TO THE TEACHING OF WRITING IN SPANISH AS A FOREIGN LANGUAGE: A CASE STUDY
}

\section{Nuria Gago}

\begin{abstract}
Computers are becoming more and more important in today's world. They are part of every sector of our society, including education. Most of the studies done so far on computer integration with educational purposes focus on the classification, and incorporation, from a theoretical point of view, of Computer Mediated Communication in the class. Unfortunately, very little empirical research has been done concerning the students' perspectives and reactions when introduced to the use of multimedia technology in the classroom. The present project was started in an effort to analyze and observer the reactions of a group of learners when exposed, in their Spanish as a foreign language class, to this sort of technology. Since the researcher was concerned with the participants' opinions, qualitative research approach seemed to be most suitable.
\end{abstract}


Para mis padres, Benito y Mari. 


\section{ACKNOWLEDGEMENTS}

You are surrounded by gifts every living moment of every day. Let yourself feel appreciation for their presence in your life and take the time to acknowledge their explendor.

- Lon Nungesser.

My sincere appreciation to the men and the women who generously gave some of their time and made possible this project.

I would like to express my deepest gratitude to all members of mi committee- Dara Shaw, for teaching me not only how to be a good teacher, but also a great person. Thanks for having introduced me to educational technology, this thesis was started because of you; Dr. Medley, for his invaluable suggestions, his proximity to this GTA who wanted to learn from him, thanks to his 'faxes,' and his extra effort that made the completion of this project possible; and very especially to Dr. María Amores, for her guidance, and time spent not only working on this thesis, but also listening, and encouraging me during the hard times, which were quite a few. Sirva esta tesis para mostrar a mi tribunal mi respeto, admiración y eterno agradecimiento.

I would also like to thank Rosa and Ana, my family in Morgantown for the last three years, for their unconditional friendship and support throughout the process. Thanks to Henrik, "el vikingo," for believing in me, and bringing happiness back to my life. And very especially, thanks to my parents, who from a distance helped me achieve my dreams.

Thanks to Leticia, and María, for the time and effort they put in this project, to Eugene, for his greatly appreciated and useful remarks, to Kathleen for giving me some of her time, and to Merche and the rest of the Spanish GTAs for their constant support. 
Finally, I wish to express my gratefulness to Tim Haak, for his kindness and valuable help without which this project could have never been started. 


\section{TABLE OF CONTENTS.}

ACKNOWLEDGEMENTS iv

Table of Contents vi vi

CHAPTER 1: INTRODUCTION 1

Purpose of the Study 3

Instructional Setting

West Virginia University and the Department of Foreign Languages 4

The Basic Spanish Course Sequence 5

$\begin{array}{ll}\text { Nuria's Class } & 6\end{array}$

“Composición: Proceso y Síntesis" 8

1. The Launcher 9

2. Primary Tool Bar 12

$\begin{array}{ll}\text { The Participants } & 14\end{array}$

1. Michelle 14

2. Amy 15

3. Hannah 15

4. Rob 16

5. Eric 17

6. Bill 18

CHAPTER 2: A QUALITATIVE APPROACH TO THE STUDY 21

$\begin{array}{ll}\text { Review of the Literature } & 21\end{array}$

Teaching Writing in the FL Classroom: New Approaches 22 and New Tools

Instructional Computing: Changing Roles of Teachers and Learners 27

Instructional Computing: Issues and Challenges $\quad 30$

Significance of the Study $\quad 34$

Research Design and Procedures $\quad 35$

CHAPTER 3: DATA ANALYSIS 37

$\begin{array}{ll}\text { Introduction } & 37\end{array}$

Computers as Students' Attention Holders and Tools of Empowerment 38

Students' Writing: A New Approach 42

$\begin{array}{ll}\text { Editing Stage } & 45\end{array}$ 
External Factors: Influence on Students' Perceptions of the Program 47

$\begin{array}{lr}\text { Limitations of the Software } & 50\end{array}$

“Composición: Proceso y Síntesis” as Word Processor 50

Special Character Help $\quad 51$

Dictionary Vs. Thesaurus $\quad 51$

$\begin{array}{ll}\text { Conclusion } & 52\end{array}$

CHAPTER 4: SUMMARY AND CONCLUSION 54

Summary of Findings $\quad 55$

Writing Assistant Software Use in the FL Classroom: Nature and Reactions

Students' Perspectives on the Use of

"Composición: Proceso y Síntesis" 56

Factors Affecting Participants' Perceptions of

“Composición: Proceso y Síntesis" 58

$\begin{array}{ll}\text { Conclusion } & 60\end{array}$

$\begin{array}{ll}\text { WORKS CITED } & 62\end{array}$

$\begin{array}{ll}\text { APPENDICES } & 68\end{array}$

$\begin{array}{ll}\text { Appendix 1- Spanish } 4 \text { Syllabus } & 69\end{array}$

$\begin{array}{ll}\text { Appendix 2- Nuria's Spanish } 4 \text { Syllabus } & 78\end{array}$

Appendix 3- Lesson Plan "El Camino de Santiago" 87

Appendix 4- Handout \#1 "Composición: Proceso y Síntesis” 91

Appendix 5- Handout \#2 "Composición: Proceso y Síntesis" 97

Appendix 6- Questionnaire \#2 100

Appendix 7- Questionnaire \#1 103

Appendix 8- Table 3: Secondary Participants’ Demographic Data 107

Appendix 9- Demographic Questionnaire 109

Appendix 10- Questionnaire \#3 112

Appendix 11- Rob's composition $\quad 115$

\section{LIST OF TABLES}

Table 1- Schedule of the Classes in the Computer-Equipped Class 7

Table 2- Primary informants' Demographic Data 19

Table 3- Secondary informants' Demographic Data 106 


\section{LIST OF FIGURES}

Figure 1- Opening Screen "Composición: Proceso y Síntesis" 9

Figure 2- Screen for Invent/New Document/La Descripción/Question $3 \quad 10$

Figure 3-Screen for Create a Conference 11

Figure 4- Screen for Special Character Help $\quad 12$

Figure 5- Screen for Thesaurus 13 
"Nothing goes by luck in composition. It allows of no tricks. The best you can write will be the best you are."

-Thoreau. 


\title{
APPLICATION OF COMPUTER-BASED TECHNOLOGY TO THE TEACHING OF WRITING IN SPANISH AS A FOREIGN LANGUAGE: A CASE STUDY
}

\author{
CHAPTER 1
}

\section{$\underline{\text { Introduction }}$}

Many educators look to educational research for evidence of technology's present and potential benefits. Although technology (especially computers) has been in use in education since the 1950's, research results have not made a strong case for its impact and quality of teaching and learning. In general, the number and quality of studies on educational impact have been disappointing. (Roblyer and Edwards 2000, 12)

'Contradictory' is the word that best defines research findings regarding the effectiveness of educational technology. Scholars' ideas and statements move from one extreme to the other, promoting computers' instructional benefits or challenging their integration into the continuum of teaching and learning.

Kost (1999) and Swan and Mitrani (1993) defend the new direction education is taking as a result of the growing use of computers, software programs, the Internet, and Computer Mediated Communication (CMC) in general. Some researchers agree with them, since this sort of multimedia technology is thought to raise learners' motivation (Bush 1999) and provide a much more individualized approach to teaching. According to Roblyer and Edwards (2000) and to Swan and Mitrani (1993), this change is very positive because it cedes more control to students over their learning. CMC is also very valuable since it facilitates instructors' access to new resources and authentic materials (Walz 1998), and helps them towards the attainment of the Standards (1999) established for the discipline they teach (Gonglewski 1999). Unfortunately, as Swan and Mitrani (1993) state, "there has been little empirical evidence that computers have produced noticeable changes in the suggested directions in traditional schooling." (42) 
It would appear that most of the research projects done that relate to technology examine either the history of technology in language education (e.g. Singhal 1999; Armstrong and Yetter-Vassot 1994; Stevens 1989) or present some of the technological resources available nowadays, explaining how these can implement language instruction (e.g. Lixl-Purcell 1999; Green 1997; Maddox 1997). However, these studies typically do not address the affective results of these applications.

Much more limited research (Swan and Mitrani 1993; Garret 1991; Kesner-Bland, Noblitt, Armington, Gay 1990) has been designed to collect data on students' perceptions and reactions towards computer use and/or "investigate its efficacy in local and carefully specified contexts." (Garret 75) Further, this research has tended to focus on applications of the Internet rather than on software (Kost 1999; Walz 1998; Green 1997). It is both the lack of descriptive research and the inconclusive results of empirical studies to date (see Wilcox and Jensen 1997; Swan and Mitrani 1993) that lead scholars such as Selwyn (1999) and Oppenheimer (1997) to question both the financial investments that are being made by many governments on educational technology and the initial excitement that these tools are provoking. As Selwyn (1999) notes,

[B]eneath such confident prophesying, there has been little, if any, sustained evidence that the use of [technology] in education will necessarily lead to improvements in instruction and learning [...] As a result, national governments are beginning to realize the need for gathering evidence supporting the salience of educational [technology] and its role in 'improving education.' (2)

Garret (1991) maintains that "concerned teachers want research reports to give them simple answers." In terms of research, it might be beneficial, then, to go beyond investigations of the theoretical strengths of such software (e.g., Bush 1997) or beyond a focus on how these tools may or may not motivate the student (Roblyer and Edwards 
2000, or Green 1997). In addition to these studies, research needs to concentrate on what students think and the way they feel when working with educational software as a means to reinforce and facilitate their learning process in the language class in general, and in the foreign language (FL) curriculum in particular. For these reasons, the present study proposes to investigate students' perceptions of a computer-mediated writing assistant program.

\section{Purpose of the Study}

The purpose of the present study is to narrow the focus of previous research through a descriptive investigation of the use of "Composición: Proceso y Síntesis" (Valdés, Dvorak, Hannum 1999), a writing assistant software program created to implement writing skills in Spanish as a FL. As the investigator was specifically concerned with the students' reactions and the significance they attach to the program, a qualitative research approach designed to provide information concerning the participants' perspectives and experiences seemed most suitable. Data collection was achieved primarily through questionnaires, oral interviews, and personal observations. 


\title{
Instructional Setting
}

West Virginia University and the Department of Foreign Languages

\author{
Almost heaven, West Virginia \\ Blue Ridge Mountains, Shenandoah River \\ Life is old there, older than the trees \\ Younger than the mountains, flowing like the breeze \\ Country roads, take me home \\ To the place I belong \\ West Virginia, mountain mama \\ Take me home, country roads. \\ All my memories gather 'round her \\ Miner's lady, stranger to the blue water \\ Dark and dusky, painted on the sky \\ Misty taste of moonshine, teardrop in my eye [...] \\ ("Take me Home, Country Roads" by John Denver)
}

The present study took place at West Virginia University (WVU), a public land grant institution "committed to the goal of equal educational opportunity for all students" (Undergraduate Catalogue 1999, 16). Since one of the main goals of WVU is to empower its students to "acquire knowledge, understanding and appreciation of diversity in languages, cultures, ideas, and peoples," (28) this institution, through its Department of Foreign Languages (DFL) provides the opportunity for students to learn several of the major modern languages spoken in today's world. This university has set as requirements for the Bachelor of Arts (B.A.) degree in the Eberly College of Arts and Sciences the completion of four semesters of the same foreign language. Although this requirement has been eliminated for the Bachelor of Science (B.S.) degree, two semesters of a foreign language are strongly recommended for that program also.

The Department of Foreign Languages, located in Chitwood Hall, is part of the Eberly College of Arts and Sciences and offers instruction in Chinese, English as a 
Second Language (ESL), French, German, Italian, Japanese, Linguistics, Russian and Spanish. Bachelor's and Master's degrees are offered in French, German, Linguistics, TESOL (Teaching English to Speakers of Other Languages) and Spanish. A Bachelors' degree in Russian is also offered. The remaining languages have only the basic and intermediate-level courses.

\section{The Basic Spanish Course Sequence}

Every semester the Basic Spanish program offers six courses (Spanish 1, 2, 3, 4, 10, and 11), which are scheduled and assigned to the Graduate Teaching Assistants (GTAs) by the Basic Spanish Program Coordinator. The training, supervision, and evaluation of these GTAs with respect to their overall classroom performance is also the responsibility of this faculty member. She establishes the instructional methodology to be followed in the classes, selects the textbooks, determines the sequence of instruction and develops course syllabi and testing criteria. All of this ensures a relatively homogeneous learning environment across all sections of the Basic Spanish program.

The main goal of these courses is to develop functional ability to communicate in Spanish. The course content includes the introduction of basic grammar as well as the teaching of reading and writing. There is a special emphasis on oral and communicative skills, and on language for real use in everyday life situations. The textbooks for the first four semesters (Dos Mundos Terrell, Andrade, Egasse, Muñoz 1998, in Spanish 1-3 and Punto y Aparte Foerster, Lambright, Alonso-Pinto, 1999 in Spanish 4) have been selected on the basis of their compatibility with course and program goals. 
The course chosen for this study was Spanish 4, described as follows:

[Spanish 4] plays a dual role in the Spanish curriculum. It is the capstone course in the initial series of language courses (Spanish 1-4), and it is also the preparatory course for more advanced study. As such, its goals are two-fold: to help [students] acquire the ability to use what [has] been learned by focusing on seven essential communicative functions in Spanish (describing, comparing, reacting and recommending, narrating in the past, talking about likes and dislikes, hypothesizing, and talking about the future), and to help [students] to achieve greater cohesion in [their] speaking and writing abilities. Further, this course will give [them] an opportunity to apply these skills as [they] learn more about Hispanic cultures through authentic sources. Specifically, the course will center around short readings selected from the textbook, accompanied by a variety of preparatory and follow-up activities. ("Spanish 4 Course Syllabus Spring 2000,” 1) (See Appendix 1)

It was the special nature of this final course in the basic program, as well as the emphasis to be placed on writing, that resulted in its selection as the setting for the research to be conducted.

\section{Nuria's Class}

In the spring semester of 2000, I taught Spanish 4 (section 007) to a group of 25 students. My class met regularly on Mondays, Wednesdays, and Fridays from 12:30-1:20 p.m. During the semester some classes took place in a regularly furnished classroom, while others took place in a fully equipped computer classroom. On eight different occasions, the class met there to work on the brainstorming of the compositions, peerediting or on other activities developed by the instructor, which required the use of multimedia technology. Table 1 illustrates the chronology of these meetings.

Because of the special nature of the study, a restructuring of the main syllabus for Spanish 4 was needed. After discussion with the Program Coordinator, it was decided to remove Chapter 5 of Punto y Aparte from my Spanish 4 syllabus (see Appendix 2). Deleting Chapter 5 gave me six additional days that were spread among chapters 1 and 3, 
since these two chapters were the ones where the compositions were to be written using the software program. I also used two of these 'extra' days to introduce the writing assistant software to the participants. This allowed them to become familiar and confident with the program before they actually began their writing assignments.

In designing my approach to the project and in developing the instructional strategies to be employed and the lesson plans to be followed, I carefully considered the educational purposes and consequences of the integration of "Composición: Proceso y Síntesis" into the curriculum. I also considered its potential to empower students to develop their writing skills and increase their awareness of the writing process.

In preparing the lessons that involved use of the software, I was cautious not to assume either a previous exposure to computers or an equal understanding of these tools on the part of the participants. I did not want the students to reject the program because of a lack of knowledge of its use, or of its features, so two class sections were dedicated to activities designed to familiarize students with the software.

Table 1: Schedule of the classes in the Computer-equipped class.

\begin{tabular}{|c|c|c|}
\hline Day of Class & Class Number & Class Activity \\
\hline MONDAY (Jan. 24 $\left.{ }^{\text {th }} 2000\right)$ & \#7 & "El Camino de Santiago" "WWW \\
\hline FRIDAY (Jan. $\left.28^{\text {th }} 2000\right)$ & $\# 9$ & Introduction "Composición: Proceso y Síntesis.” \\
\hline MONDAY (Jan. 31 $\left.{ }^{\text {st }} 2000\right)$ & $\# 10$ & Introduction "Composición: Proceso y Síntesis." \\
\hline FRIDAY (Feb. $\left.4^{\text {th }} 2000\right)$ & $\# 12$ & Brainstorming Composition \#1 \\
\hline MONDAY (Feb. $\left.7^{\text {th }} 2000\right)$ & $\# 13$ & Writing Composition \#1 \\
\hline FRIDAY (Feb. $\left.18^{\text {th }} 2000\right)$ & $\# 18$ & Peer-editing Composition \#1 \\
\hline MONDAY (March 20 $\left.0^{\text {th }} 2000\right)$ & $\# 27$ & Brainstorming Composition \#2 \\
\hline FRIDAY (March $\left.24^{\text {th }} 2000\right)^{2}$ & \#33 & Peer-editing Composition \#2 \\
\hline
\end{tabular}

\footnotetext{
1 "El Camino de Santiago" (The Way of St. James) is a famous pilgrimage that takes place in the North of Spain. Catholic people from all around the world go to the city of Santiago de Compostela to visit the remains of the Apostle St. James.

${ }^{2}$ Due to the density of the syllabus, in-class time was not provided to work on composition \#2.
} 
As Table 1 shows, I developed a web-based lesson plan (see Appendix 3) for the first class session in which the software was to be used, which was actually the seventh class meeting of the semester. The theme of the lesson was "El Camino de Santiago." Its purpose was to accustom the participants to the computer classroom that would be used later on in the FL class and, at the same time, to give them more control and confidence in the use of the computers in the room.

Following the familiarization lessons, the software program to be used in the study, “Composición: Proceso y Síntesis,” (Valdés, Dvorak, Hannum, 1999) was introduced to the students (meetings number $9 \& 10$ ). These were the only two classes in the semester held in English. In order to facilitate understanding of the main features and organization of the program, and for the students to have a reference point when working by themselves with “Composición: Proceso y Síntesis," handouts (see Appendices 4 and 5) were provided. The software and its features are discussed in detail in the next section.

\section{"Composición: Proceso y Síntesis"}

Based on the study of different teaching methodologies and learning theories, some researchers suggest that writing skills should be taught emphasizing the process while students are generating and constructing their compositions (Zamel 1989, Zamel 1982). This would indicate that the almost exclusive focus of earlier approaches on form and grammar has evolved into a greater emphasis on both the organization and the content of the compositions.

"Composición: Proceso y Síntesis" is a writing assistant software program created to develop and encourage the writing skills of students of Spanish as a second (L2) and/or foreign language (FL). Twenty-five copies of "Composición: Proceso y Síntesis” were 
loaded on machines in the Computer Assisted Language Learning Laboratory (CALL Lab) of the Department of Foreign Languages so that the informants could work on their compositions outside of class.

The program is structured so that students have constant access to the main window where the Launcher and the Primary Toolbar, the two backbones of the program, are displayed (see Figure 1).

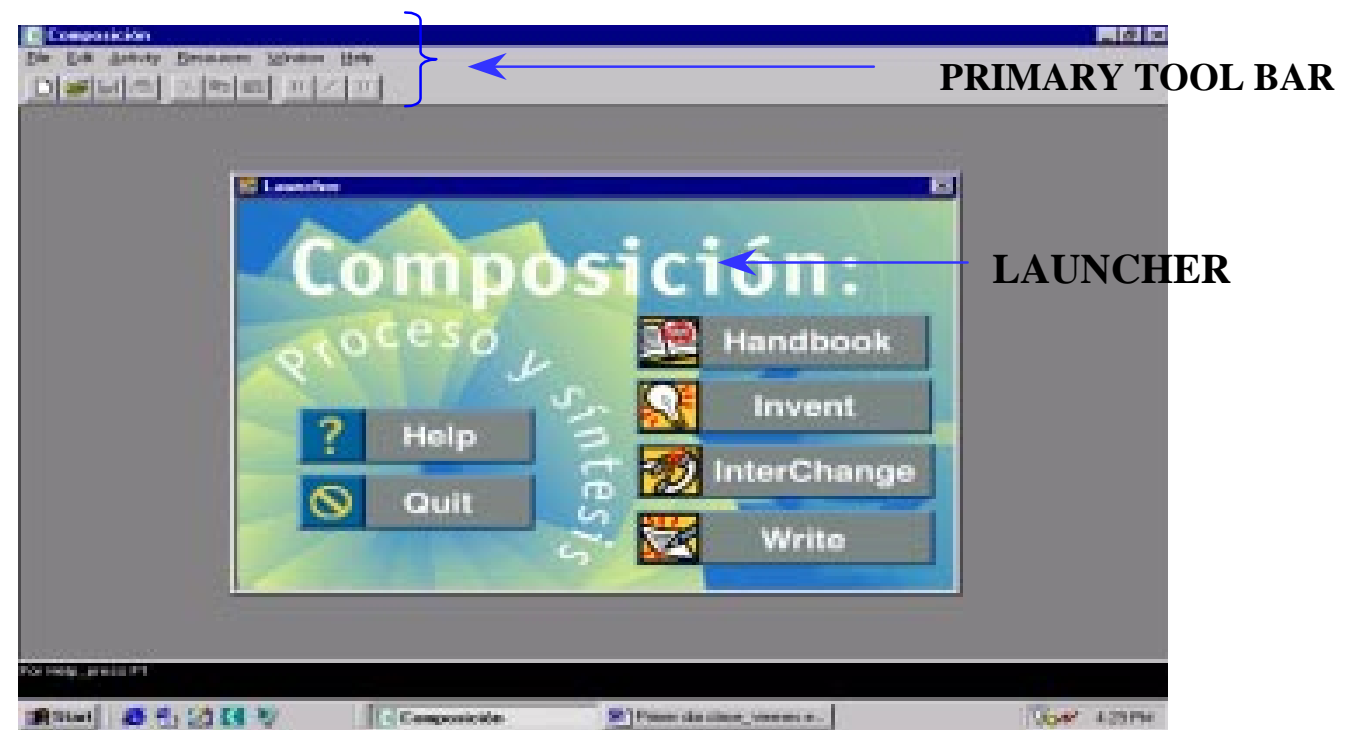

Figure 1

Opening Screen

\section{The Launcher.}

There are four main buttons, which serve as the main tools of this writing assistant software. These tools are labeled Handbook, Invent, InterChange, and Write. Two icons on the left: Help and Quit, are navigation buttons. The former allows users to obtain information about the content of the program; the latter is used to leave the program.

The Handbook is divided into six different chapters. Each one focuses on a particular writing format (e.g. descriptions, argumentation, etc.). Explanations are 
provided on how to collect and organize ideas. This section also includes a Verb Reference with a complete list of Spanish verb tenses, and a glossary of grammar terms which can be accessed in order to obtain information about specific topics such as subjunctive mood, direct/indirect objects, etc. Grammatical explanations are in English; however, the remainder of the handbook is displayed completely in Spanish.

The Invent (or brainstorming) section focuses on the pre-writing stage of the composition. Depending on the purpose of the piece of work to be written (an exposition, narration, etc.) "Composición: Proceso y Síntesis" will display a certain set of questions (see Figure 2 below) in order to orient the students and facilitate the brainstorming of their ideas.

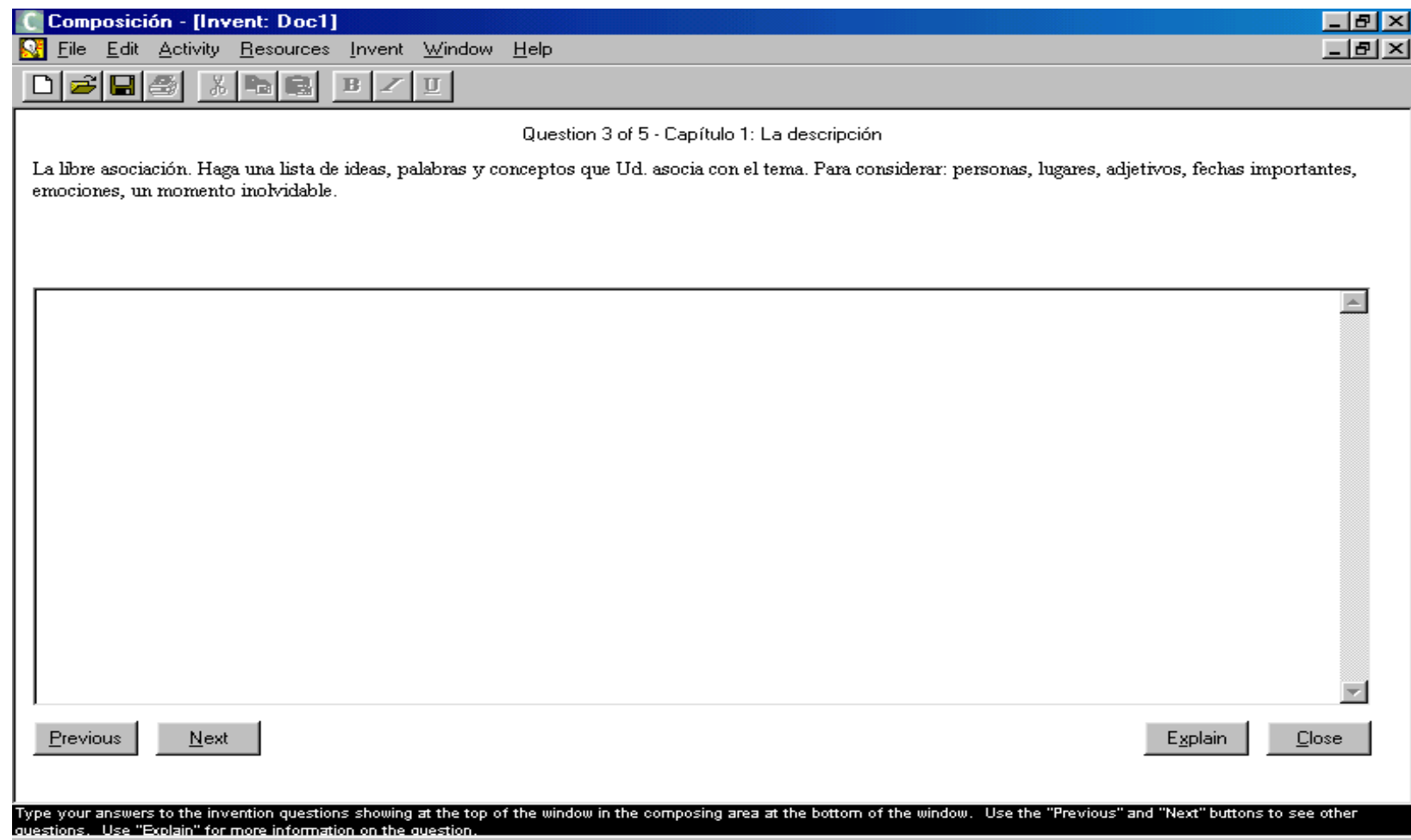

Figure 2

Screen for Invent/New Document/ La Descripción/Question 3 
The Navigation within the Invent section is mainly controlled by the 'previous' and 'next' buttons, which allow users to move forward to the following question and/or to go back to the previous one (See Figure 2). The explain button paraphrases the question asked and converts it into simpler words.

The InterChange feature is only available on the institutional (teacher's) version of this writing assistant software. It offers the possibility for learners to chat within the FL classroom, under the direct supervision of the teacher. Students can either join an existing conference or create their own, again, at the discretion of the instructor. Figure 3 is a representation of the "create a Conference" screen.

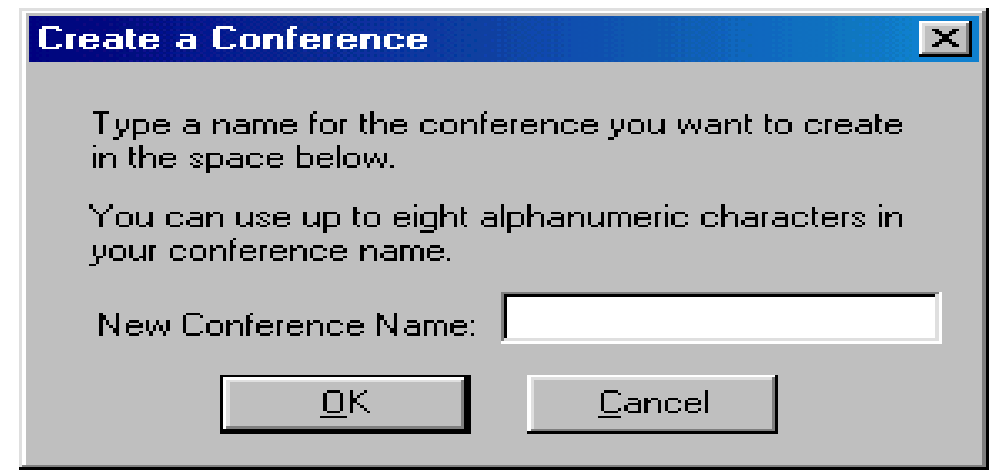

Figure 3

\section{Screen for Create a Conference}

“Composición: Proceso y Síntesis” has its own Spanish word processor which is accessed by the Write button. Most of the basic features of other word processing programs are available in this Spanish writing assistant software. Users can bold, underline, italic, change fonts, control the line spacing, cut and paste their documents, etc. This feature also makes it possible for the user to save files. 


\section{Primary Tool Bar.}

The Primary Tool Bar provides access to most of the program tools, which are also available through the Launcher. Such is the case of Special Character Help, used to incorporate Spanish symbols such as ' $¿$ ', unique letters such as ' $\tilde{n}$ ', and/or the written accents on the vowels (e.g. 'é'). (See Figure 4).

\section{Figure 4.}

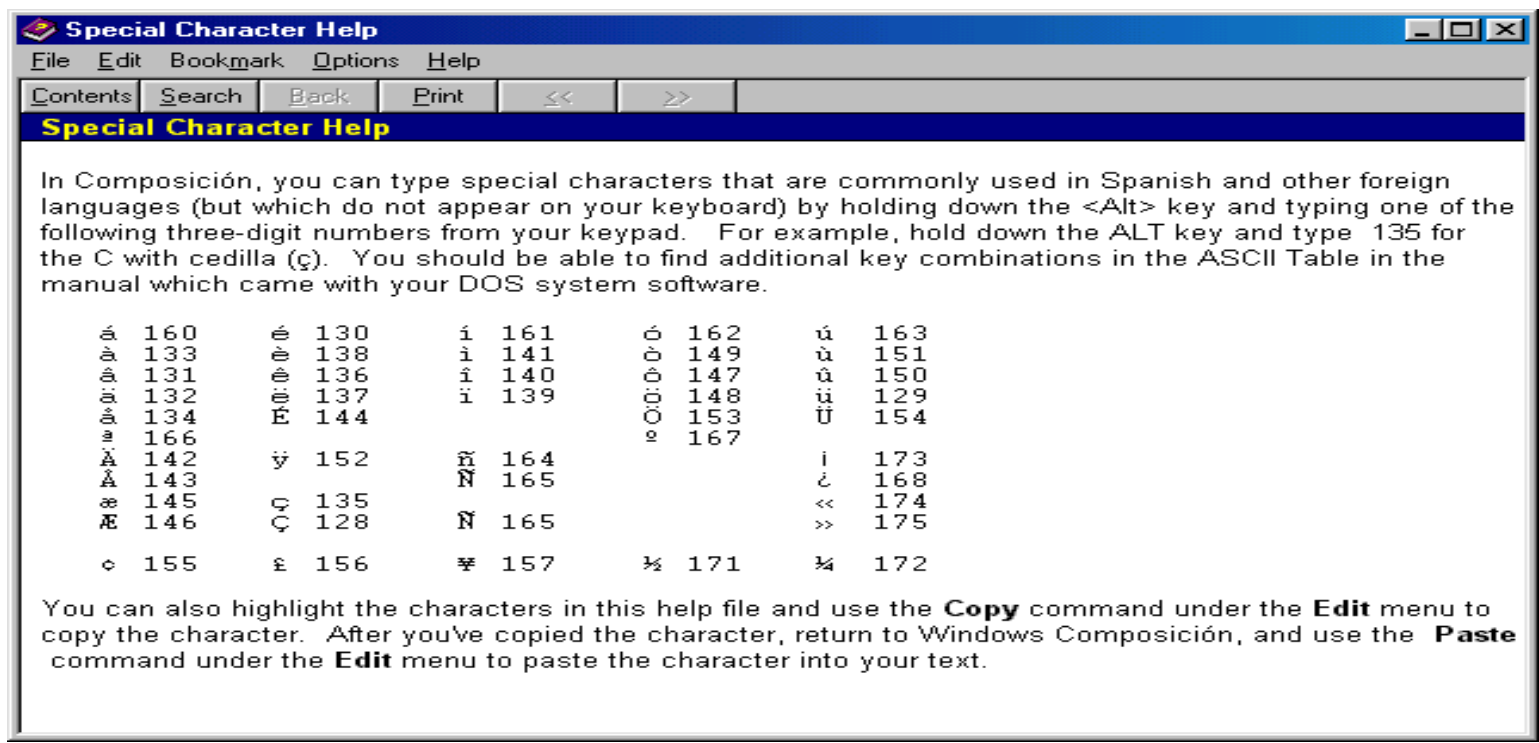

\section{Screen for Special Character Help}

However, there are some tools (e.g. find and replace or Thesaurus,) which can only be accessed through the Primary Tool Bar. The former works as in commercial word processors: users type the word to be found, and substitute it for the one to be incorporated. The latter provides both 'synonyms' and 'antonyms' for many Spanish words. To use the tool, students just have to type in the word and then click on "synonym" or "antonym" (See Figure 5). The software further facilitates the editing of compositions through its Spell Check tool, which can be employed to confirm the correct spelling of words. Since this program does not underline or otherwise highlight misspelled or erroneously used words, students must proof read the document by 
themselves. Additional details on "Composición: Proceso y Síntesis" can be found in Appendices 4 \& 5 .

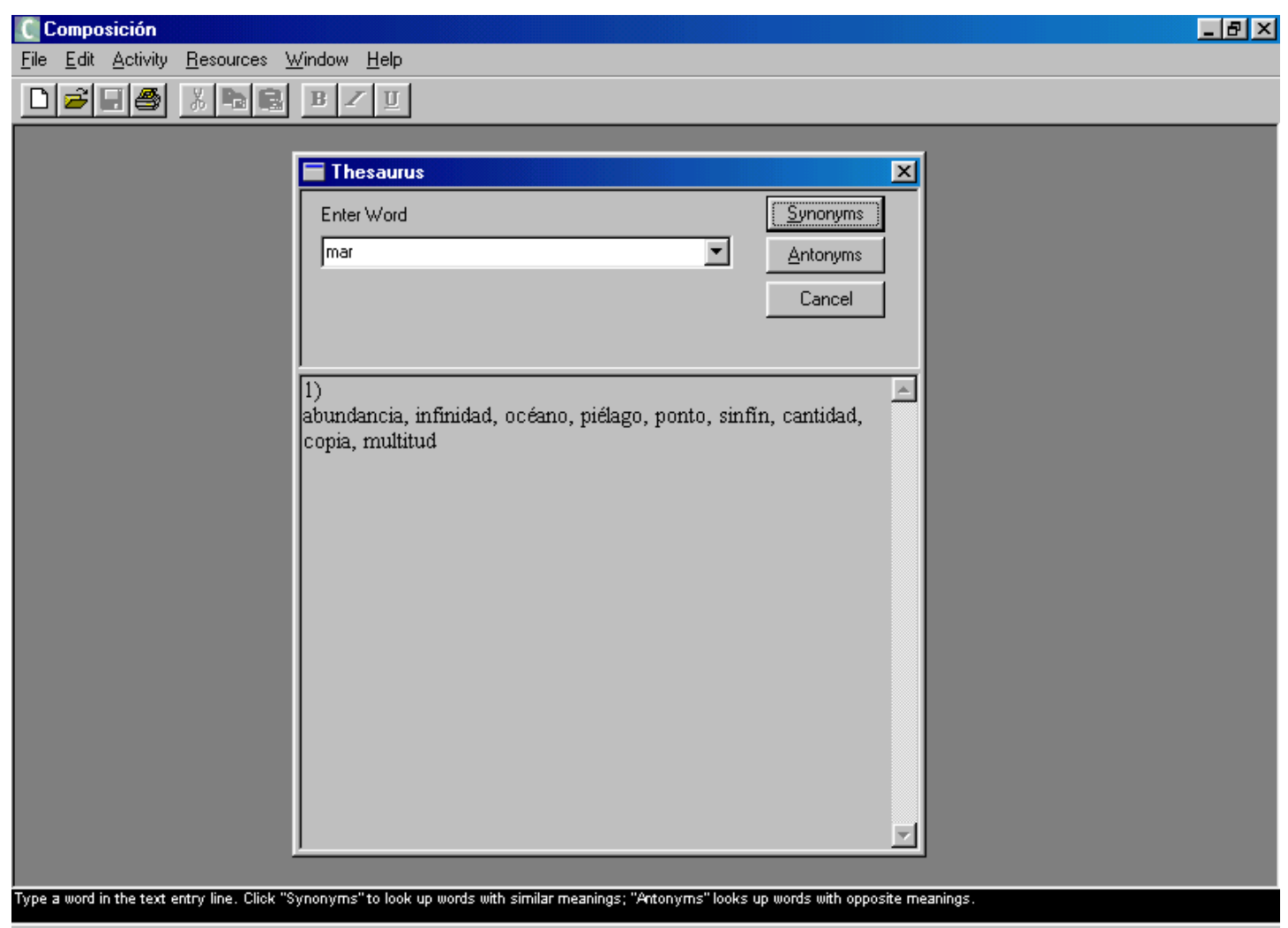

Figure 5.

Screen for Thesaurus. 


\section{The Participants}

The six primary participants in the study were: Michelle, Amy, Hannah, Rob, , Eric, and Bill ${ }^{3}$. The secondary participants were Rose, Stephanie, Jane, Carol, John and George.

1. Michelle.

Michelle was a Caucasian female twenty years of age. She was a psychology major who planned to work in the future with children or to conduct research in either deviant behavior or domestic violence. Her amiable and easy-going character, as well as her self-confidence and eagerness to learn and participate, made her an asset in the classroom. She wanted to improve her Spanish communicative skills, and made excellent use of each opportunity given in class to talk in the second language. When possible, she answered the questionnaires in Spanish. For example, in questionnaire number 2 (Appendix 6), when she was asked about what she liked most about this class, she said: "Que hablamos mucho en clase y eso me ayuda a hablar más.” (That we talk a lot in class and that helps me to talk more) $)^{4}$.

Michelle was very concerned with the development of her writing skills. She explained to me how much she liked to write, but how aware she was of her limitations in the language:

In a regular English class I like writing the most, because you know, you can get your opinion across. In Spanish class, probably I like writing a little bit less 'cause it's harder for me to convey 'cause I know what I wanna say, but it's harder for me to say it in Spanish.

Her attitude towards computer use in the classroom in general and

\footnotetext{
${ }^{3}$ The names of the participants have been changed to maintain their anonymity.

${ }^{4}$ Translation has been provided by the author for the convenience of the reader.
} 
"Composición: Proceso y Síntesis" in particular was rather positive. As she said, the program allows students to improve their vocabulary, which is extremely useful when writing in a FL because:

you can look up in the Thesaurus, and you know, we have pretty limited vocabulary in Spanish, so you know, we keep on using the same word, like tengo, comer, you know and you can look it up and find out other words, I like that.

\section{Amy.}

Amy was a nineteen-year-old female psychology major very concerned with children. Her personality was rather different from Michelle's. Amy was very shy, both in and outside class, but she always showed her great interest and motivation to learn Spanish. It was this positive attitude that helped her improve her participation grades. She did not do very well on the first exam and on quizzes at the beginning of the semester, and blamed her previous Spanish teachers for such a bad performance. Nevertheless, over time, her hard work produced better results and an improvement in her grades, her selfesteem, and her confidence.

Amy had had some previous experience with computers, and liked using them in class: “ [I]t's different, as I just said it's a change. It's not straight book work all the time [...] I've never had a Spanish class like this, so that's it, it's cool." She liked the software program from the beginning, but found some parts difficult to understand.

\section{Hannah.}

Hannah, twenty-two, was the oldest of my main informants. She was selfconscious about being older than most of her classmates. This political science major, whose goals in life include working for an intelligence agency, was the most reluctant to participate of my students. Hannah took this to the point of hardly talking in class, and 
sitting down either at the back of the class or by the door, just in the event she needed "to leave the room quickly in case of a panic attack." She was a hard worker though, and made improvements all through the semester. She always asked me at the end of the class about her performance in the class, or came to show me that she had done the activities assigned. Hannah also came to see me during my office hours to go over her mistakes on the compositions, and to see the way these could be improved.

Early in the semester, when questionnaire \#1 (see Appendix 7) was distributed, she admitted having used computers in previous classes, and sent e-mails or accessed the Internet frequently in everyday life. Consequently, she was not apprehensive about the use of "Composición: Proceso y Síntesis." She pointed out that the program was especially helpful for her because it "helps out to learn better [...] [when] I'm stuck on a word and don't have anyone around to help me then the computer can." Despite Amy's and Hannah's reserved personalities in the classroom, both of them were very thoughtful and portrayed their ideas in a very objective way when talking to me.

4. $\underline{\text { Rob. }}$.

Of the main informants, Rob was the one who most surprised me. He was a very self-confident nineteen-year-old. From the first days of class he showed his interest in the language (he was a Business and Foreign Language major), and appeared to be confident of his ability to communicate his ideas and express his opinions. Nevertheless, once we started with the oral interviews, his responses tended to be rather terse:

Nuria: How do you feel in class, Rob?

Rob: All right.

N: How do you like it? Do you think it goes fast, easy...?

R: It goes all right.

$\mathbf{N}$ : What do you like most?

R: I don't know. I like writing the papers that's what I like most. 

$\mathbf{N}$ : And what don't you like?
R: Nothing.
$\mathbf{N}$ : You can be honest, I'm not gonna fail you because you don't like what I do.
R: I don't like going to the computer lab, I prefer writing my paper another time, I prefer spending class time going over the chapters and stuff.

In our conversations, he seemed to be intimidated. He blushed many times during the interviews, as well as when I asked him to stay at the end of the class to talk about my research and to make an appointment for the interviews.

His answers on the questionnaires were much more straightforward and sometimes even rude: "I hate stupid 'brainstorming' activities and making outlines." It appears that he was much more comfortable and relaxed giving his opinion in writing rather than orally.

Rob seemed to be full of contradictions. There was neither a consistency in his attitude towards the use of "Composición: Proceso y Síntesis" nor an apparent reason for his shift in receptivity of using the piece of software. In fact, I felt that sometimes he was answering what he thought I expected him to say. I perceived that all he was interested in was completing the interviews and questionnaires as soon as possible.

\section{Eric.}

I must admit that hearing that I was going to have Eric in my class worried me somewhat. It was the first day of classes, and I was in one of the Spanish GTAs' offices checking where our former students were, and who was going to be their teacher that semester. As I was reading my list, one of the teaching assistants smiled and told me to be careful with this twenty-year-old political science major. She advised me to keep him calm, since he had a tendency to want to take control of the class and influence the other students. 
On the first day I did, in fact, perceive him to be as he had been described. Eric was showing a potentially disruptive attitude. When asked “¿dónde está Austin?” (where is Austin?), he responded in English: "everybody knows where Austin is.” I said, also in English: "Yes, everybody knows, in English, where Austin is, but I want you to say it in Spanish.” At that point, he answered: "está en Texas" (It's in Texas). This immediate confrontation avoided a possible disintegration of the class structure. Over time, as I got to know him better, I realized that there was not that much of an attitude problem. It was just his easy going character, and his way of showing his excitement and motivation towards Spanish.

He was especially interested in the culture, and also wanted to improve his writing skills:

I think writing in Spanish is very important. I think writing in any language really aids you mastering the language you speak. It'd be difficult to speak a language fluently if you couldn't write. It's easier to see it on paper than it would be to correct everything you say.

This, together with his familiarity with computer use, resulted in a rather positive, though critical, attitude towards the use of "Composición: Proceso y Síntesis" in class.

6. $\underline{\text { Bill. }}$

The last of my primary participants was a twenty-year-old history major named Bill. Of all my main informants, he was the least motivated to learn Spanish, and the only one defining what he liked in the class more or less in terms of lack of difficulty or "less work." It seemed that he was not particularly interested in developing his skills in the language, but rather just in completing the class in the easiest possible way: "there is no way I would take this class again but if I did I would like to use computers." 
Bill showed throughout the semester a preference for computer-use in the class.

He had, like the other participants, had some experience with this technology before, and used it frequently in everyday life. He seemed to feel rather confident when working with “Composición: Proceso y Síntesis.” It appeared that his interest in the software arose primarily from his perception that computers would make it easier for him to complete his work, and not that he particularly enjoyed using the machine. As he said, "that's better than sitting in the class. I like working on a computer rather than doing class work." He later confided that when he heard that the group would be using computers, he "figured out that the class was going to be easy."

Table 2 provides information on each of the six primary participants involved in the study. For further information on the secondary participants, see Table 3 in Appendix 8.

Table 2: Primary informants' Demographic Data.

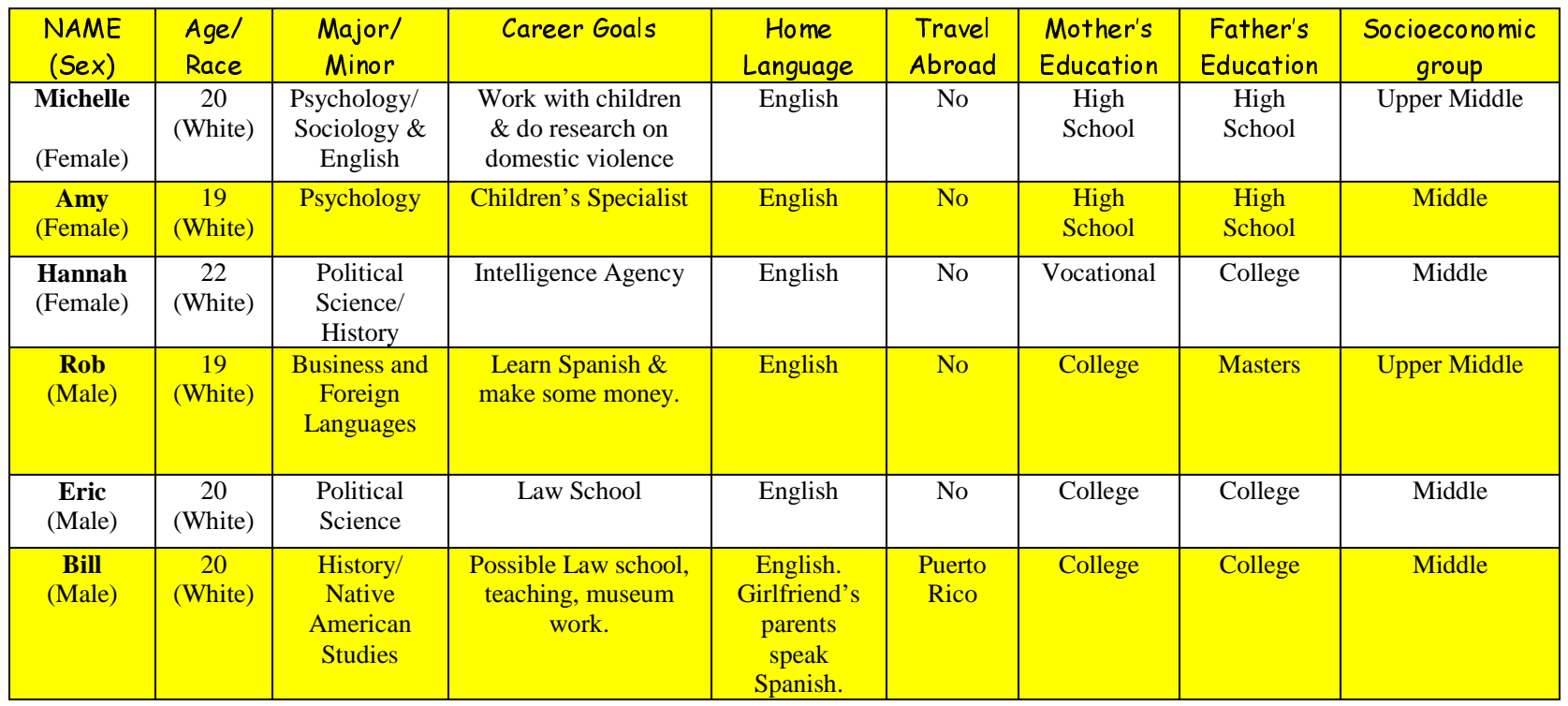


In summary, the data gathered were analyzed in an effort to determine students' perceptions of writing assistant software used in a Spanish as a foreign language classroom. Further, an effort was made to determine the significance that learners attach to what they were doing while using a writing assistant program, including the values they ascribed to the process. Finally, the role that individual factors such as previous experience with computers, training sessions, and the participants' writing habits were also investigated in terms of the influence they might have on the informants' reactions and opinions.

Chapter 2 will address the review of literature that forms the basis upon which the present research has been developed, the research questions will be posed, and the research design and procedures explained. 


\section{CHAPTER 2}

\section{A Qualitative Approach to the Study}

\section{Review of the Literature}

Much of the research to date related to the use of technology in the classroom has focused on applications of the Internet, "a concentration of thousands of computers of various sector of society such as education, business, government [...] [where] each individual $[\ldots]$ brings something to the whole $[\ldots]$ and the end result is a vast amount of information." (Singhal 1999, 2) This Computer Mediated Communication is considered by many to be a unique learning environment which, if well employed, may implement and improve both students' performance and teachers' instruction in the FL class (Singhal 1999; Gonglewski 1999; Green 1997).

In 1999, the Standards for Foreign Language Learning in the $21^{\text {st }}$ Century, a major volume on the teaching and learning of FL, was published. The standards were developed to be used as a template that reflects the knowledge that should be expected from the students along a continuum from kindergarten through four years of college. The document addresses "five goal areas which make up foreign language education: communication, cultures, connections, comparisons and communities. None of these goals stands alone; all are interconnected" (Standards for Foreign Language Learning in the $21^{\text {st }}$ Century 1999,27 )

Since the publication of these goals, a good amount of the literature has connected the Internet with the Standards. For example, Kost (1999) affirms that the Internet allows users to access a wide variety of authentic materials that range from written texts (such as on-line magazines and books) to live music and images. These materials enhance cultural 
understanding of the FL, which is one of the goals promoted by the Standards: "students [will] demonstrate an understanding of the relationship between the practices and perspectives of the cultures studied." (Standards for Foreign Language Learning in the $\underline{\left.21^{\text {st }} \text { Century } 1999,50\right)}$

The Standards also foster critical thinking and the ability to establish connections. They state that

as a consequence of learning another language and gaining access to its unique means of communication and ways of thinking, students [...] begin to examine a variety of sources intended for native speakers [...] As they become more proficient users of the foreign language, they seek out materials of interest to them, analyze the content, compare it to information available in their own language, and access the linguistic and cultural differences. (56)

In this sense, the Internet is very useful because it "emphasizes language study in its cultural context" (Singhal 1999, 4) and promotes the construction of knowledge based on connections, thanks to its interactive nature (Bush 1997). Beyond the Internet, however, are those stand-alone pieces of software and programs tied to print media (e.g. textbooks). This study, as mentioned in Chapter 1, focuses on one such writing software package, "Composición: Proceso y Síntesis."

\section{Teaching Writing in the FL Classroom: New Approaches and New Tools}

Approaches to teaching writing as a second or foreign language have undergone a tremendous change in the last three decades. This, in turn, has resulted in a shift in the paradigm that controls writing strategies. At the same time, new tools have emerged to implement and facilitate the students' performance in the classroom (Reed 1990). 
There are two major approaches to teaching writing in the FL. The productcentered approach, also known as the traditional paradigm, promotes the establishment of certain rules and principles of rhetoric to achieve the best possible writing product (e.g. paragraph, composition, report, etc.) (Kroll 1991). Traditionally, this approach controlled error production since students' writing was evaluated based on syntax, spelling and punctuation usage rather than on creativity or on the ability to communicate ideas (Yukio 1998). Because writing was envisioned as a linear process, instructors did not encourage revisions. Compositions were taken as first and final drafts. A paper written was synonymous with a paper done (Barnett 1989).

Nevertheless, researchers' investigations (Scardamalia and Bereiter 1986; Zamel 1983; Hairston 1982; Lay 1982) began to provide some insights into the basis of "embarrassing stories about college graduates who can't pass teacher competency tests." (Hairston 1982, 81) These studies began to sensitize educators to the poor results obtained with the use of the traditional paradigm. Simply stated, many of the students exposed to the product-centered approach were not only unable to communicate their thoughts but also could not organize their ideas in a coherent and cohesive way.

This dissatisfaction with product-oriented writing prompted teachers to begin to look for new approaches to the development of this important skill. As Albert (1993) states, "instead of focusing on sentence combining, grammar and on the final product, scholars tried to discover what [was] involved in the [...] process of writing." (7) Murray (1976), as cited in Hairston (1982) "suggests that if we want to teach students to write, we have to initiate them in the process writers go through, not give them a set of rules." Followers of this revised approach believe that students, the same as real writers, do not 
compose their essays in a linear way. On the contrary, they move back and forth, plan (pre-write), revise, and change ideas as well as the primary organization of these ideas through several re-writes, out of which their compositions emerge in final form (Hairston 1982).

In the pre-writing stage, writers generate the ideas that will be developed and organized further on to create the content of the essay (Spack 1984). Among other things, brainstorming activities occur in this phase that facilitate and encourage class discussion on the particular topic students will be writing about. Zamel (1982) emphasizes that "this dialogue allows [learners] to hear and thereby evaluate the clarity of their writing." (201) At this early stage of the writing process, teachers should not pay a lot of attention to the form and organization of the ideas, because students will have opportunities further on to improve the coherence and cohesion of their compositions (Barnett 1989).

Zamel (1982) portrays writing as a painful process: "students [talk] about the pain involved in the act of writing." (201) It seems logical, then, for teachers to provide guidance throughout the process, as well as to encourage the preparation of multiple drafts, to edit and revise the work as it is being done. This iterative process many allow the learners to experience "the feeling of accomplishment $[\ldots]$ when they are satisfied with what they have written.” (Zamel 1982, 201)

Albert (1993) has observed further that "studies of second and foreign languages have lagged behind those in English as a Native Language. Thus, early researchers in the area of writing in the L2 started to think of the applicability of L1 studies in the L2." (13) Not only the methodology employed to teach writing in the L1 was adapted to the FL classroom, but also the tools used to facilitate the students' writing process (Kroll 1991). 
Writing instructors in English as L1 moved a step forward to integrate what Roblyer and Edwards (2000) classified as productivity software (e.g. word processing programs such as Microsoft Word, or Corel Word Perfect) into their language classes. Multiple benefits were attributed to these interactive and very innovative materials, which, even though they were not intentionally developed for educational purposes, rapidly became an essential part of the language class. Professors became so interested in using word processors that universities across the United States began to offer computer-assisted English composition and rhetoric courses. Educators promoted the use of word processing programs to facilitate their students' development of ideas, as well as the general organization of their compositions (Garret 1991). Roblyer and Edwards (2000) add that word processors are an asset in the language curriculum since they improve both teachers' and students' productivity. They allow users to easily organize, modify and store different forms of texts and, at the same time, polish the appearance of the document, giving it a more professional image.

In summary, the professional literature seems to conclude that the integration of this sort of productivity software improves students' performance, and that learners in classes where this kind of multimedia has been integrated tend to write and revise more (Roblyer and Edwards 2000). Similarly, Swan and Mitrani (1993) note that there is a tendency for students to participate more actively in the class as well as to have more regular attendance when software applications are used. It seems that, in general, learners feel more attracted and motivated when using computers instead of preparing and working with handwritten or typed documents (Harris 1995). 
As FL educators, institutions, CALL Labs, and publishing houses began to recognize the great potential of productivity software, they began to develop, adopt, and adapt these sorts of tools to meet the needs of their specific courses (Pusack and Otto 1997). It seemed obvious to practitioners though, that a series of modifications needed to be made in software programs in order to address the differences between L1 and L2, and the subsequent constraints of writing in a FL. This is how FL instructional software was born. Roblyer and Edwards (2000) attribute the rapid development and popularity of instructional software to its ability to deliver instruction using challenging and motivational activities. Hooper (1997) and Steven (1989) add that its popularity among teachers has to do with the ability of the software to develop intuitive and creative thinking in the students.

Because of the many aspects and areas of interest that need to be covered in the FL curriculum, there is an extensive amount of instructional software available on the market. Many of these programs share common features, making it rather difficult to organize a taxonomy of these products. However, there seems to be some consensus on several categories, including: Drills and Practice software, Tutorials, Simulations, and Instructional Games (Roblyer and Edwards 2000). Within this taxonomy, however, there is not full agreement on how FL/L2 writing assistant software should be classified. Roblyer and Edwards (2000), together with some publishing houses, place them in a category to themselves, called writing assistant software for the FL class. Programs in this group generally include a set of extra features (e.g. verb reference, dictionary, thesaurus, grammatical explanations, etc) that transform word processors into a more useful tool that is able to provide students relevant, accurate and complete information 
even when the teacher is not available (Jia, Winser and Chewng 1996). This exposure to new resources, together with the possibility for the users to construct knowledge through associations, created a need for the adoption of new teaching techniques in those classes where such CMC was integrated.

\section{Instructional Computing: Changing Roles of Teachers and Learners}

Lee and VanPatten (1995) maintain that educators should stop playing the role of the titan Atlas ${ }^{4}$ of Greek mythology. They explain that teachers should lift the weight from their own shoulders and teach their students to become critical thinkers, using a variety of sources outside class. The wide variety of interactive software, together with the endless amount of information the Internet provides, are two excellent tools to be used to foster the use of additional sources of knowledge and to change the roles of teachers and students.

Owen (1995) in his article "Poems that Change the World: Canada's Wired Writers" describes a project at Simon Fraser University in Vancouver (Canada), which promotes electronic mentoring. Professional writers were hired to read and respond to students' writing. This project was very motivating and engaging for the participants because it showed them that there is a whole world of knowledge beyond the classroom and the teacher. Sharing their ideas with the writers gave students confidence in their writing abilities: "it was clear that the writers were interested in the students and in the writing they produced. It was an odd pleasure [as stated by the learners] to be taken seriously." (Owen 1995, 50)

\footnotetext{
${ }^{4}$ According to Greek mythology, Atlas was a titan condemned to support the heavens upon his shoulders for all eternity.
} 
The Internet is not the only computer-based technology able to facilitate changing roles within the FL classroom. Some of the instructional software available on the market has been created to improve different linguistic skills (e.g. Drill \& Practice), some other programs generate and stimulate critical thinking as well as organize the writers' ideas (e.g. writing assistant software). These programs facilitate students' learning and relieve teachers of the more mechanical tasks associated with the process. Consequently, instructors can redirect their activities and provide a much more individualized approach to instruction (Roblyer and Edwards 2000). Armstrong and Yetter-Vassot (1994) however, caution educators to use these multimedia tools only when needed, since the use of technology is not about how many bells and whistles we can add to the classroom. It is about empowering the learner. It is about encouraging students to leave behind the notion that learning means rote memorization. It is about explorations and the realization that there are multiple paths to knowledge. (483)

This conceptual change forms the basis for the new paradigm. Just as instructional computing is changing the role of teachers, so, too, are the students affected. Research shows how instructors have stopped assuming full responsibility for what is going on in the FL classroom and how they have realized that students need to be more active in order to promote and improve their learning (Finkel and Mosk 1983). Thus, new roles have been adopted in the FL class. Teachers are becoming "guides on the side" (Kost 1999, 309), "knowledge breakers" (Maddox 1997, 13), architects whose main function is to model the students' learning processes and, at the same time, promote critical thinking (Roblyer and Edwards 2000).

At the same time, today's learners are facing new responsibilities they have not confronted before. They are becoming more active and responsible for their own 
learning. They "are not any more a passive audience, receptive vessels into which knowledge is poured." (Lee and VanPatten 1995, 4). As Bush (1997) observes, students now are controlling the materials according to their own needs. In this sense, the interactive nature of the Internet and of both productivity and instructional software is very appropriate to promote students' control since they give users freedom to navigate within the program at their own pace (Allessi and Trollip 1991). What is more, Swan and Mitrani (1993) have portrayed the positive influence that the control gained over the materials, and consequently over their own learning, had on at-risk students. Their results seem to suggest that the participants learned faster when classes took place in the computer-based facilities. The authors further noted that students' attendance improved when teaching methodology included computer-mediated communication.

Kinzer and Leu (1997) describe how instructional computing provides an excellent setting for the shift to more active learner goals. In what was called The Reporter Project, they explored the reactions of a group of students when assigned the task of acting as real writers and reporters in one of their courses. The objective of that class was to edit a newspaper in the L2. Both individual and group work was promoted and required in order to facilitate the accomplishment of the assignment. The information needed was primarily obtained through the Internet and other multimedia sources such as CD-ROMs and electronic dictionaries. According to the investigators, The Reporter Project showed that

students made statistically significant improvement in their recognition and use of elements such as main ideas, supporting details, and cause and effect relationship [...] Their writing was also more cohesive than their control-group peers who were taught using similar materials and sequences but without the use of the technology. (Kinzer and Leu 1997, 128) 
Some researchers maintain that computer use in the classroom does not ensure higher motivation (Burnett 1999; Allessi and Trollip 1991). Nevertheless, Warschauer (1996) concludes that this multimedia technology, if well employed, may permit the creation of a relatively risk-free environment able to improve students' interest, since it provides them with the possibility to explore and test their creativity without fear of any type. Roblyer and Edwards (2000) corroborate this interest, affirming that "students seem to like interactive activities because they promote creativity, self-expression, and feelings of self-efficacy and result in professional-looking products they can view with pride." (13) Shucart (1999) and Summers (1990) point out that learners tend to be more attracted to the content displayed in the software programs. They note that the visual design of the different pieces of software seems to capture and maintain learners' attention for a longer period of time than do other materials (e.g. textbooks) used in more traditional classes.

\section{Instructional Computing: Issues and Challenges}

The governments of many countries (among those, the United States) are especially committed to the use of CMC at all levels of instruction. The Clinton administration, for example, has spent millions of dollars trying to improve and facilitate access to new computing technologies in every school and university in the U.S. (Hammer 2000; CNN Interactive, April 12, 1998). However, computers cannot yet be taken for granted in every school or home in the United States. In many educational institutions of this country, the goal has been to provide a "fully-interactive language learning environment," (Garret 1991, 81) but faculty still have to adapt their courses to 
the places and times available for them to use such resources, which may be a location other than their own classrooms.

Despite the efforts to make instructional computing more accessible to everybody, some research findings suggest that there is a widespread growth of computerphobia and technological disillusion (Selwyn 1999; Burnett 1999; Oppenheimer 1997). Roblyer and Edwards (2000) pose the persistent question that many teachers cannot stop asking: "if computer programs [can] be written to do anything, why could computers not be programmed to teach?" (81) If the answer is yes, then the possible implications scare those who view this sort of interactive technology, not as tools to enhance teaching and learning, but as the enemy that they are going to encounter and fight against so that it will not replace them.

Burnett (1999) reports on the anxiety and powerlessness that many teachers feel when using instructional computing as part of their class. These educators see themselves as being required to become involved in a task which is very time consuming and which, in their opinion, is not so useful since it adds complexity to what they are trying to accomplish instead of facilitating its process. But teachers are not the only ones that experience a feeling of anxiety when working in a computer-based environment. Students with limited access and experience with computers may also feel uncomfortable with this multimedia technology. This is why Roblyer and Edwards (2000) and Maddox (1997) emphasize the necessity of adequate training sessions for those who will be using CMC.

Other researchers refer to the 'technological gender gap' to express "the idea that males and females have different technology related attitudes, behaviors and skills." (Canada and Brusca 2000, 1) According to some investigators, females are less interested 
and more afraid of computer-use than males (Wilcox and Jensen 1997; Hawkins 1985). However, Turkle (1984) explains that such negative attitudes and anxiety towards computers showed by females may not necessarily be related to their gender. On the contrary, they could be primarily provoked by several factors such as inexperience in the field (caused by limited access to or a bad experience with computers), a lack of interest in the technology or even in the particular task they are working on. Zerh (1998) and Lawley (1993) have both suggested that women tend to be more interested in the practical side of computing, rather than using computers for recreational purposes, or in learning language programming (i.e., of a more theoretical nature). They would prefer not to take any course at all rather than to take one from which they perceive that they are not going to benefit. If this is the case, then courses supported by writing assistant software should be of interest to them.

Some researchers question the theoretical advantages of computing technology (Selwyn 2000; Burnett 1999; Oppenheimer 1997). They question the role computers should have in the classroom and explain that the class should be a place where discussion, interaction, and creativity should be encouraged. In their opinion, this sort of technology impedes these more critical interactions. They claim that much of what was originally expected from this medium when it was first introduced has not yet come true. They use the findings of Cuban (1986) to bring into question, once again, the theoretical benefits of computer use in the classroom. Roblyer and Edwards (2000) respond to these criticisms and to reports of computerphobia by maintaining that multimedia technology, by itself, is not likely to produce any benefit for either the teacher or the student. These authors believe that the incorporation of technology into the FL curriculum requires 
substantial re-thinking and redesign of the syllabus and of the ways in which media are to be used. But above all it requires training and time for the users to adapt and understand the tools. They maintain that a lack of awareness of the multiple benefits and possibilities of instructional computing is what causes the negative attitudes and reactions portrayed by Burnett (1999). Armstrong and Yetter-Vassot (1994) suggest that teachers should stop "limiting [...] students to print-based resources and [...] allow them to broaden their knowledge of the history and literature of the [target language] TL while at the same time expanding their technology literacy." (482)

In summary, the challenge confronting today's educators is to stop being afraid of instructional multimedia and to begin to consider the many advantages it may have to offer to foreign language teaching and learning. It is important for instructors to become aware of the way technological interactivity and design not only increases the interest, participation and attendance of the students, but also positively influences their performance in the class. At the same time it is necessary for educators to assume their new role in this changing age in which they are living. As a profession, we need to move forward towards a more student-centered classroom where students have more control and are more responsible for their own learning, and where they are given the opportunity to access new materials and sources of knowledge other than the teachers themselves. We need to see instructional technology is one of the tools that can be utilized to empower students to become more effective learners. At the same time, however, educators must be attentive to the voices of the students as they begin to interact more and more with instructional technology. For this reason, the current study was designed to investigate 
the student perspective on the use of a specific type of software in a fourth-semester Spanish class.

\section{Significance of the Study}

The current study poses questions based on the premise that a more complete understanding of student interaction with multimedia technology in the foreign language classroom will occur when the accumulated research considers both the context of instruction and the participants' perspectives. Indeed, participants' voices may challenge prior assumptions about the development of writing skills in the computer-mediated foreign language instruction. Therefore, this study proposes to investigate the following questions:

What is the nature of writing assistant software use in the foreign language classroom? What happens when the software is introduced? How do students react?

* What significance do students attach to the use of "Composición: Proceso y Síntesis" in the computer equipped classroom and/or in the CALL Lab? What values do they ascribe to the program? What is their perspective on the program and how is this perspective affected, if any, by their writing habits prior to taking the class?

* What role, if any, did individual factors such as prior experience with computers and training sessions play in the students' perceptions of the program and/or in the development of their writing skills? Did the instructional setting, time constraints and accessibility to the writing assistant software influence their attitudes about the use of the program? 


\section{Research Design and Procedures}

The value of qualitative research "lies in the power of its language to display a picture of the world in which we discover something about ourselves." (Silverman 1997, 19) Since the goal of the present project was to gather data on what participants see, their perspectives and the significance they attach to the use of writing assistant software in a fourth semester Spanish class, it seemed most appropriate to approach this investigation from a qualitative perspective.

Three main techniques were employed in order to answer the research questions posed earlier in the chapter: questionnaires, oral interviews and class observations. Another source of information, quite unanticipated, came from two Graduate Teaching Assistants not associated with the study. One was a GTA in Spanish and the other worked in the Chemistry department. They both reported comments to me that had been made to them by some of the participants in the study. These comments were also used as a means of corroborating findings and triangulating the data.

Demographic questionnaires (see Appendix 9) were distributed to gather data on the informants' backgrounds and interests. Three additional questionnaires (see Appendices 6,7 and 10) were given to obtain information about the participants' 1) computer skills prior to taking my class; 2) reactions to the software used; 3) methods employed when writing their compositions in Spanish; and 4) perceptions of how the introduction of the writing assistant software affected their writing habits. The data from the questionnaires provided access to a broad range of information for subsequent analysis. 
In addition to the demographic questionnaires, two oral interviews were conducted with each of the main participants. In accordance with the recommendations of Wilcox and Jensen (1997) these interviews were held outside of class. The setting was a small departmental library, which was a much more comfortable environment that promoted friendlier interaction between the investigator and the primary informants. Each interview lasted about 15 to 20 minutes, thus providing approximately 5 hours of data recorded on tape. As Amores (1996) suggests, these interviews were conducted in English, the main language of the students, in order to "overcome any semantic differences that might exist between subjects and ethnographer and to encourage trust and comfort in the informants." (88) She also notes that use of English may help students avoid anxiety since their Spanish linguistic ability might not have been high enough for them to explain some of the concepts in the second language. However, Michelle, one of the primary informants, did not hesitate to respond in Spanish even though I had previously started the interview in English.

Observations, as Marshall and Rossman (1989) state, are critical in qualitative research. They turned out to be extremely useful in this study since they provided good information concerning the students' reactions while having contact with the software both in the computer-equipped classroom and in the CALL Lab. Data gathered through the observations reinforced and expanded the quantity of information obtained from the written questionnaires and the two oral interviews, so that triangulation could be ensured. 


\section{CHAPTER 3}

\section{Data Analysis}

\section{Introduction}

As an instructor, I perceived early in the semester, when the classes started, an apparent lack of interest in the study of Spanish on the part of my students. When asked to volunteer in the class, they did not even raise their hands to participate and/or express their opinions. The following is a typical scenario for the first class sessions:

Nuria: El primer día de clase de español, ¿qué pensásteis de la profesora? (The first day of Spanish class, what did you think of the teacher?) [No answer]

Nuria: ¿Pensásteis que soy agradable, mala? (Did you think that I was nice, mean?)

[No answer]

Nuria: ¿Qué opinásteis de la clase de español? (What did you think about your Spanish class?

No immediate answer. After a while some students started answering: "muy difícil." (Very difficult) Others said: "fácil y divertida." (easy and funny)

This passiveness in the classroom transformed eventually into a more positive attitude and interest in Spanish culture and language after the first weeks. During this period, the students came in contact with Computer Mediated Communication (CMC) by means of a web-based lesson plan I developed called "El Camino de Santiago" (see Appendix 3). The primary objective of the activity was to introduce students to one of the major national holidays in Spain, and at the same time familiarize them with some of the main features of one particular celebration. Some time later in the month, participants had their first contact with the other computer-based tool they were going to be working with: “Composición: Proceso y Síntesis.” From the beginning of this project I perceived the excitement that this sort of technology was bringing to the students. My observations were confirmed later on by the comments Rose made, which were reported to me by her 
chemistry GTA. Rose remarked to my colleague about how much she liked the Spanish 4 class that she was taking because they were using computers and the Internet to improve their Spanish. Being given the opportunity to work with an interactive tool where they could access all kinds of information dealing with the Spanish language and culture seemed to capture the participants' attention and improve their interest in the subject. One example of this enhanced interest was that, when working on the activity of "El Camino de Santiago," all groups but one were accessing the web pages in Spanish even though an English version was also offered.

Some research findings have pointed out that the use of computers constitutes an incentive in the language learning process of students (Moskowitz 1995; Swan and Mitrani 1993), while others have questioned their efficacy, especially among female students (Wilcox and Jensen 1997). A comparison of research findings, as shown in earlier chapters, has also revealed contradictions as to the efficiency of the integration of computers in the FL classroom. Consequently, in order to investigate these issues, a range of ethnographic techniques -- questionnaires, interviews and observations -- were used to illustrate the different intentions that might lie behind students' behavior, since much previous research has neglected the possible meanings that behavior entails. The following section record and analyze students' interaction with the writing software as they worked on their own compositions.

\section{Computers as Students Attention Holders and Tools of Empowerment}

Eric: I think that sometimes people can stare at the book all day and lose interest, and maybe a computer could hold their attention better. And it could be more interactive and not as monotonous as when writing assignments. 
Examining not only Eric's, but also the other main participants' responses seemed to confirm Waschauer's (1996) ideas that the use of computers created a much more motivational and risk-free environment where students were more willing to explore and test their creativity in the foreign language class. One student, Michelle, commented on her perception of using "Composición: Proceso y Síntesis" in the class:

I am more motivated 'cause I have a clearer idea of what I am going to write. It is a little bit better [because] it gives you a place where to start.

Moskowitz (1995) and Swan and Mitrani (1993) establish that the empowerment and control that computers give to users over their decision-making and learning is a major motivating factor for them. An analysis of the main informants' performance, reactions and answers indicated that "Composición: Proceso y Síntesis" positively influenced and transmitted to students a sense of 'power,' a control over their writing in Spanish. As Michelle said:

I like when we go to Armstrong [where the computer classroom is located] and we start answering the questions about the format of the paper. It'd give you a more clear idea of the paper rather than wasting the night before it's due.

In speaking of the usefulness of working with computers, Hannah added:

In general I tend to be rather insecure on my compositions in Spanish. That is why, after brainstorming a little, I usually go to my teacher for help. But for the things that I don't understand there is now the computer to answer all the questions, and that makes me feel better.

She further attested that the Invent tool gave her the security and confidence she needed to confirm that she was "on the right track."

The literature reviewed on motivation and anxiety suggests that students' reactions to computer-use in class depends on their gender. According to Wilcox and Jensen (1997) and Shashanni (1993), males and females have different reactions towards 
the use of instructional software programs in the classroom. This is most commonly known, as explained in Chapter 2, as the 'technological gender gap.' It seems that women tend to be less interested than the males, and consequently, less comfortable and selfconfident when having to work with these tools. This was also true in Burnett's (1999) study.

In the present study, I observed some apprehension in my female main informants when I explained the nature of the present project. I could sense that my words were having an effect on them. They kept on looking at each other, moving their eyes wondering what was going on. I was not sure at that time whether their reaction had something to do with the specific computer-based nature of the course, the introduction of the writing assistant software as part of the curriculum, or it was just the anxiety that Scarcella (1992) states usually takes place in most FL classes. According to the initial data that I had gathered, it seemed that my research might confirm the 'technological gender gap' theories of Canada and Brusca (2000) and Wilcox and Jensen (1997). However, both oral interviews and questionnaires demonstrated later on that only one of the female participants was slightly worried about having to work with "Composición: Proceso y Síntesis." It was Amy who said: "At the beginning I thought: this is gonna be really hard. Oh my God! I am not gonna be able to do this! But it's easy."

It was obvious that the training sessions helped Amy realize that the software was not as difficult to use as she expected: "I like it now. First time...I'd never had a Spanish class like this so...that's it. It's cool though.” Eventually Amy's self-confidence improved, making her feel better and more relaxed in the class. The change in her attitude 
was also evident when she started participating and volunteering more and more often at other times during other classroom activities.

Hannah showed anxiety as well, but in her case it was produced by the idea of having to write in Spanish and not by the use of the program itself:

I guess I thought that it would be a lot harder and that that was more I had to do. Because you said that we were going to be focused on writing and I get nervous about writing, I guess I don't think my compositions are that good. It's harder to write an actual story or paragraph.

Hannah, as mentioned earlier, was the shyest of my main participants. From the way she talked, she seemed to have very low self-confidence, and not having had Spanish in two semesters did not help her to eliminate this feeling. Nevertheless, from the very beginning Hannah had a very positive attitude towards the software. She liked it very much because, as she said, "it sets up an outline for my composition. It helps me out to learn better or [...] if I get stuck on a word or... and I don't have anyone around to help me then the computer can."

None of the male main informants showed anxiety, not even towards the idea of having to write in Spanish. Both Eric and Bill were really happy and comfortable with “Composición: Proceso y Síntesis" and more than willing to use it in class. As Eric explained: “[it] made things a little bit easier, I think. I've used computers for everything, so why not foreign languages?" Among the male main informants, Rob was the only one who disliked working with the program. He was not anxious about its use. On the contrary, he felt, as he wrote in questionnaire \#1, "very confident" in front of computers. It was simply that he did not like going to the computer classroom since he would rather spend that time in the regular classroom working with the book and studying grammar for his exams. He commented: "I don't like going to the computer lab. I prefer writing my 
paper another time. I prefer spending class time going over the chapters and stuff." When

I took the class to the computer-equipped classroom to use "Composición: Proceso y

Síntesis" to brainstorm ideas, Rob started surfing the web or talking to John, his

classmate, instead of doing what he had been assigned. His lack of motivation may be

directly connected to the little significance he gave the program, which he considered to

be "a knocked down version of Word, with some reference materials built in."

\section{Students' Writing: A New Approach}

Oral interviews, questionnaires and personal observations showed the wide

variety of reactions learners had to practicing the steps and stages of the writing process.

From the answers given, I observed that there was a general trend to omit the pre-writing stage that the process-centered approach emphasizes so much:

Nuria: In the past, how did you write in Spanish?

Michelle: I would, well, it depended on how much time I would have. Sometimes I would write it down on a piece of paper, in Spanish. I would never really write it in English 'cause I would have to translate it, "cause it gets too difficult to reorganize your sentences. So anyway, I just wrote on a piece of paper and then type it or I would just get on the computer."

Before taking this class, Michelle told me that she would "never really give much importance to brainstorming for ideas." Not doing so "was never that big of a problem" since the topics for their compositions were, as Jane said, "very easy [...] so I didn't really do any pre-writing or brainstorming [and] just went straight forward and wrote [...] from my mind." Time and the lack of difficulty of the compositions to be written were not the only rationale given by the main participants for their reluctance to brainstorm. In this sense, Rob was more straightforward, explaining that brainstorming ideas was "a waste of time [...] I never do it. I mean, it could help if you like to do that, I mean, I see that it could help you to make outlines, but I don't need it personally." He also stated: "I 
don't even do that [brainstorming] when I have to write a paper in English. I just sit down and write straight forward." Such a direct statement served to make his posture clear.

During the class sessions we spent working with the brainstorming tool, Rob would be surfing the web looking for information about the other courses he was taking, or chatting with other students. I realized that he was rejecting my efforts to change his way of doing things because he had been using it for a while and it worked. He was very confident in his writing: "mi composición es muy buena" (my composition is very good), and no program, and no GTA was going to tell him how to write in Spanish.

With writing habits granting so little importance to brainstorming, I expected a very negative reaction towards the use of "Composición: Proceso y Síntesis" since it focused so much on the same strategies during the pre-writing stage. I found however, that the participants' attitudes changed later on in the semester with the introduction of the software. Hannah, for example, liked the Invent section very much: "I think that helped a lot. I use that actually, as basis for my paper, as an outline [...] It offers questions that I can answer instead of me having to come up with different subjects."

The observations of the participants while working in the computer-equipped classroom with the Invent section (brainstorming facilitator) showed that students were in fact making the effort to gather their ideas (pre-writing stage), at least when using the writing assistant software. Almost everybody, with the exception of Rob and John, was focused on answering the questions provided by the brainstorming tool of "Composición: Proceso y Síntesis." In fact Stephanie, Amy's friend who was also in the class, while chatting with me in the Spanish office, mentioned that "it [was] great that everybody in the class like[d] "Composición: Proceso y Síntesis" and its Invent section." She also 
added that "everybody seem[ed] to be very focused while working with it, and that [was] cool." As Michelle observed, "[teachers] told us what to write about [...] [so] it was not that big of a problem, but it's easier now with the brainstorming thing. If it's out there for you, it is easier to follow." These remarks suggest that their writing approach changed as they became more aware of the extent to which the pre-writing activities could improve their composition.

It appeared that even Rob's perception of both the program and the importance of its Invent tool, although contradictory, dramatically changed at the end of the semester. In fact, on questionnaire \#3 (see Appendix 10) he affirmed that even though "I did not like classes in the computer-equipped classroom [...] I gave a little more importance to [the brainstorming] now than when I first started using it."

Hannah, Michelle and Eric considered the Invent tool to be, as Eric said "one of the best aspects of the program.” In Hannah's case, she became more confident in her abilities as she used the brainstorming tool. While I observed her in class, I perceived neither hesitation nor fear when she was using the writing software. On one occasion Hannah missed the class where we worked on brainstorming for their compositions. However, not having been exposed to the ideas discussed in class was not as much a problem for her as it used to be. On the contrary, she seemed very relaxed when we talked on the phone, since she knew that she could get her work done in the CALL Lab brainstorming her ideas on her own before starting to write.

Only two of the main participants, Bill and Amy, did not give much importance to the brainstorming component over time. Bill viewed the Invent tool as a useful feature that facilitated his writing, which was unnecessary. He asserted: "It helps, but I don't 
think it's needed." Amy, on the other hand, commented that she did not care about the brainstorming because "sometimes the questions [...] are difficult to understand."

\section{Editing Stage}

All participants recognized the importance of the form and appearance of compositions. This affirms Roblyer and Edwards' (2000) position that writing assistant software tools facilitate users' productivity by providing them with the ability to manipulate and edit documents. When asked about the most relevant features of “Composición: Proceso y Síntesis,” Hannah, Bill and Eric all mentioned the Spell Check that comes with it. As Hannah said, "I like it. I like the Spell Check. I like that I can add the accent marks, or the question marks, or the exclamation, and I don't have to write it. It looks better, more professional."

Bill said that what he liked most about the program was that when he copied his document from his Word Perfect software into "Composición: Proceso y Síntesis" all the 'red and green' underlining spell check disappeared. Eric and John on the contrary, missed this particular feature very much. As Eric said,

I think it should have one of those red and green lines like in Word and Microsoft Word [sic], because you can go all through the whole thing and nothing is gonna jump out at you. But when you have the underlining you know when you do and it makes proof reading along less bothersome.

John, on his part, stated:

[I wish] it would catch when you are writing on, or when you did something improperly, or used the wrong verb tense [...] I need it to say this is feminine, you are using masculine, I would love it to tell me that, 'cause I run through with what I am writing and don't think about that.

Observing the informants' behaviors while writing their compositions in the

CALL Lab gave me extra information about the significance they attached to the 
software. I noted that George and Carol, two of my students, who were not among the main informants, were only concerned (the same as Bill) with transferring their documents from their word processing programs to "Composición: Proceso y Síntesis" in order to improve the appearance of their compositions, and add accents or other Spanish diacritical marks. In the particular case of Carol, all she wanted was to open her document (which she had written at home because she missed the brainstorming class), check the spelling of her words, and improve the general appearance by marking the accents and question marks.

Rob, Eric, Amy, Michelle, and Stephanie all agreed that another feature, which they thought was excellent, was Handbook. As Stephanie explained:

I like the program mostly because information about verbs is right there to help you [...] Since I knew that the verb lists and conjugations were right there, I wasn't hesitant to try harder to conjugate the verb correctly or use the proper tense. Otherwise, when I'm in a hurry, I have a tendency to go on what I remember instead of finding my book and looking it up.

The Thesaurus was also very important for them. Michelle's comments were representative of the group. She said that it helped to improve their "pretty limited vocabulary in Spanish [...] [and to avoid] using the same word like tengo, comer [...] and also to find out other words." However, all of the students signaled that a bilingual dictionary was still needed. As John said,

It certainly could have included a regular Spanish-English dictionary, so you could find the word that you were looking for rather than having to know a synonym for it, because with ["Composición: Proceso y Síntesis"] not having it, I still had to have to go to a Spanish-English dictionary to find the exact word. 
The lack of such a useful tool and the consequences this may have had on the main informants' perceptions and significance of the program will be discussed in the next section.

\section{External Factors: Influence on Students' Perceptions of the Program}

Magazines, newspapers, and TV news reports reflect the significance computers have in today's society, and the efforts of institutions and governments to improve and facilitate Internet and computer access to everybody (CNN Interactive April 14, 1998; CNN Interactive April 28, 1998). WVU provides students contact with this technology by means of its multiple computer labs distributed all through the campus. The immediate result of this availability of hardware is that all participants in the study were confident of their ability to use computers. When asked, all six main informants said they had had considerable contact with this particular technology and that it was becoming essential in their lives. For example, Amy reported: "I check my email, look stuff up in the Internet, instant messenger, write papers." "Everything happens on line," Eric said, making clear that this pro-technology era we are living in has positively influenced his feelings towards computer use. It appears that factors such as external persuasion (through the media, for example), and prior exposure and experience with these tools, do have a positive effect on the participants' behavior and their relaxed attitudes towards the use of computers in general. This attitude was also reflected in the use of "Composición: Proceso y Síntesis.”

A second factor affecting the informants' perception and significance attached to this writing assistant software was the process of familiarization that took place before 
the participants were told to use "Composición: Proceso y Síntesis" as a work tool. In this sense Hannah commented:

[The orientation classes] helped me because I knew where things were at, made it easier to go when I actually had to write my paper. Otherwise, I would have sat there for a while trying to figure out where everything was.

Michelle observed: "the activity helped to know exactly what the capabilities were. You know, if you needed to look up any word, you went to the thesaurus." She added though, "it's not a hard program to use, I think. If you know how to use Word, if you know how to use Microsoft Word, then you can figure out how to use Composición because it's pretty self explanatory [...] It's easy."

Although there were a number of machine crashes that occurred in the computer classroom during the semester in which the study was conducted, only one of my main informants (Michelle) mentioned the failure of the machines as a constraint in using this type of technology: "I don't like that sometimes, I don't know if it's the program or the computers, but sometimes it won't work, and I don't think that is the program but just the computers." None of the other students in my class but John, computer science major, ever referred to this episode: "there have been difficulties as far as the program is not running, crashing, it is difficult to print, you know, the various technical difficulties we've had." Such lack of criticism may let us assume that those inconveniences were not seen as a major constraint by the majority of the participants nor were they perceived as a weakness of the software program itself.

Out of the six main informants, five of them liked having class in the computerequipped classroom. Bill, for example, felt that it: "was a good break from lecture $y$ (and) class work," and Michelle observed: "it was not routine." Rob was the only one who 
"would rather stay in class working on grammar and studying for his exams." Despite enjoying the "change" of classrooms, most of the participants stated that having to go to the CALL Lab to continue working on their compositions was rather painful and inconvenient. As Michelle expressed it, "I like going to the computer lab, but when it comes to write the composition I would rather do it at my own house 'cause it's more convenient. So I like learning in class and then doing the homework at home." This was not possible, since the software was only available in the computer classroom and in the CALL Lab.

Michelle was not the only student who thought this way. Stephanie also "didn't like having to go downtown [to the CALL Lab] just to use the program." She added that there was "nothing specifically wrong about the program itself [since it] helped [her] on [her] composition." It seems that the setting, as well as the limited access to the CALL Lab, have been two major factors influencing the attitudes of the students. However, as Eric commented, most of the main informants liked the features and the usefulness of the software:

I would say, I would give it an A and I think that the only reason why people would give it less than that is just for the inconvenience of going [to the CALL Lab]. It would be good if the lab opened on weekends; that is gonna be the biggest problem people are gonna have. Just the program itself, I don't think anybody can have any problem with it, 'cause it's organized pretty well. It's just a matter of access.

Lixl-Purcell (1999) and Moskowitz (1995) talk about how computers simplify students' work (depending on their needs), making it more appealing. Early in the semester I noticed the participants' excitement when they became aware of how “Composición: Proceso y Síntesis" could facilitate their writing in Spanish: "It makes writing easier," Amy said. In fact, the interest I perceived in that class was corroborated 
later with the comments about "Composición: Proceso y Síntesis" that Eric and Rose made to two of their former GTAs. Eric, for example, when talking to his Spanish 3 graduate teaching assistant and without him being aware of my presence in the Spanish office, said: "I love my Spanish 4 class. We are using computers to improve our writing in Spanish. I like that."

Nevertheless, even though they felt more confident about the use of the program, as they got to know it they rapidly became aware of some of its limitations. They saw how this writing assistant software did help them, but it could not facilitate their writing as much as they had originally expected. Informants agreed on the need for the publisher to improve some features in the program in order to turn the students' writing into a simpler process.

\section{Limitations of the Software}

As users of the software, students felt that the word processor should be modified, the Special Character Help should be simplified, and the Thesaurus should be supported by a bilingual English-Spanish/Spanish-English dictionary.

"Composición: Proceso y Síntesis" as a Word Processor.

Rob considered the program to be a "knocked down version of Word with some reference materials built in that needs more features like Spanish spell-check [...] [together with] the little red lines under [the] words." The main participants thought that the software should be able to provide grammatical and stylistic responses the way other word processors do. They wanted, as I heard them discuss in class with each other, a writing assistant software that was able to tell them when they used a word improperly, or when agreement between nouns and verbs/nouns and adjectives was incorrect. They 
considered the spell check to be useful, but not as helpful as it should have been, and definitely more inconvenient than they expected.

\section{Special Character Help}

Main informants clearly demonstrated all through the semester their dislike of the 'character help' offered by the program. They found it to be very inconvenient when having to incorporate Spanish special characters such as 'ñ,' ¿’' and accents such as 'ó' into their compositions. It was tiresome for them to have revert to ASCII code each time

they needed to use a Spanish character. In fact, some of the participants preferred to use a pen to mark their vowels instead of entering the code, or would just not add any accent at all instead of having to type the commands. As Hannah said: "I wish it didn't have the key padding character to go back and look and find the number and then go back. I wish I could just type one button and [it] comes up and replaces it." No matter how tedious this task was, though, some main informants ended up memorizing some of the commands, as noted in Amy's response to a question about the code for "ñn" when she said: "I don't know, but 'á' is Alt+160."

\section{Dictionary vs. Thesaurus}

The instructor perceived participants' efforts to incorporate new "fancy" words that could improve the appearance and form of their written assignments. The next example, extracted from Rob's composition (see Appendix 11), is an illustration of this use:

“Aunque profesor Díaz-Plaja es muy perito en encontrar los problemas de la sociedad Americana, no nos da soluciones." (Even though Professor Díaz-Plaja is very skillful in pointing out the main problems of American society, he does not give us any solutions). 
Despite the students' interest and satisfaction with the Thesaurus, all six main informants agreed on the necessity of a bilingual dictionary English-Spanish/SpanishEnglish. In this sense, Eric stated that "it needs a Spanish-English dictionary. It doesn't have enough references too, I think. It has a Thesaurus, but you can use more.”

As an instructor, I agree with them on the necessity of this extra tool since, as a consequence of their limited vocabulary, some of the efforts made to include new vocabulary turned into an erroneous use of the words. Such is the case, for example, of perito in the example shown before. Definitely, a dictionary could have helped learners to look up the meaning and appropriateness of the synonym to be used.

\section{Conclusion}

The data collected and analyzed as a part of this study suggests that the integration of writing assistant software in the FL class is perceived by students as a positive component in the development of their writing skills. Contrary to what some researchers have claimed, this sort of technology integration does not appear to produce anxiety in the learners, but rather increases their interest in the class because of the control it gives them over their own learning. It may be that the change to a less traditional scenario where teaching and learning take place, as well as the newness of the materials employed, combine to produce the enthusiasm for the software reflected in the current study.

The data confirm that the initial passiveness shown by most of the participants towards the pre-writing stage where they need to brainstorm their ideas changed as the semester progressed. By the end of the term, there seemed to be a general appreciation of the usefulness of the Invent section included within "Composición: Proceso y Síntesis." 
However, as the investigator perceived through the observations, questionnaires, and interviews, the main reason that most students liked the program was because it enabled them to improve and edit the formal appearance of their documents. Participants especially valued the grammar in the reference tool, the thesaurus, and the character help provided. Nevertheless, it was the limitations of these features together with the lack of the characteristic feedback given (e.g. underlining the word to be edited) by some of the most popular word processing programs and the necessity of a bilingual dictionary English-Spanish/Spanish-English which attracted more criticism and detracted from the overall appreciation of “Composición: Proceso y Síntesis.” 


\section{CHAPTER 4}

\section{$\underline{\text { Conclusion }}$}

Even though computers have been used in the classroom since the 1950's, it was not until the late 1980's that they began to influence the way teaching and learning are conceptualized. As research studies were conducted to determine the impact of this technology on instruction, most of the investigations focused on the use and incorporation of computers and the World Wide Web into the classroom. Unfortunately, hardly any of the studies concentrated on either the effectiveness of instructional technology, on the affective results, or on students' perceptions of such interactive applications.

More recently, scholars have investigated the important role that Computer Mediated Communication could play in education, pointing out the potential benefits of multimedia tools when used for instructional purposes (Kost 1999; Bush 1999; Shucart 1999; Summer 1997). Swan and Mitrani (1993) for example, declared that the interactivity of such tools especially increases students' participation and motivation, and positively influences their performance in the class. However, there remains a lack of empirical evidence, as both Selwyn (1999) and Oppenheimer (1997) explain, that questions the initial enthusiasm and belief in the power of multimedia technology.

The present study grew out of an effort of the investigator to comprehend aspects of the students' perception related to computer-use in the foreign language curriculum. Thus, three research questions were posed to investigate: 1 ) the nature of writing assistant software used in the FL classroom, together with the learners' reactions when this tool is introduced, 2) the significance and values attached by students to the use of 
"Composición: Proceso y Síntesis" and how their perspective is affected, if any, by their writing habits prior to taking this Spanish class, and 3) how individual factors, such as training sessions, time constraints, or accessibility affect, if any, the participants' perceptions of the writing assistant software. As an immediate consequence of the interest in gathering data concerning the participants' perspectives and experiences, a qualitative research was the method used to better approach this project.

\section{Summary of Findings}

\section{Writing Assistant Software Use in the FL classroom: Nature and Reactions.}

"Composición: Proceso y Síntesis" is a multimedia software created to facilitate students' writing in Spanish as a foreign and/or second language. The interactive nature, designed to give control to the users over the program, allows students to easily access both editing and brainstorming tools.

The analysis of the data gathered in the present study seems to confirm that such interactivity and the capacity that the software had to provide information and help to write in Spanish, had a very positive influence on participants. Apparently, the architecture of the program, and more specifically its contents, invited learners to take more risks and feel more comfortable with their work. It also seems that the rather novel way in which "Composición: Proceso y Síntesis" displayed the information contributed to the ability of the program to attract and maintain participants' attention and interest.

Only one informant showed apprehension to computer integration in the classroom. It seems that the training sessions, together with the ease of use of the software program, were enough to allay any fears, and reduce the insecurity of those who were not accustomed to the use of this sort of technology. 
Data obtained illustrated that the apprehension caused by the one student was not caused by the incorporation of CMC but to the nature of the FL class itself, where students were expected to write and speak in Spanish. Thus it appears that the data obtained in the present project do not support the theory of the "technological gender gap.' On the contrary, once "Composición: Proceso y Síntesis" was introduced, students in general, regardless of their sex, appeared to show a great enthusiasm about the idea of using computers to enhance and facilitate their learning in the FL class.

\section{Perspectives on the Use of "Composición: Proceso y Sintesis"}

Data analysis showed that participants had a special interest in the editing tools included in the writing assistant software. In the informants' opinion, the Spell Check, Special Character Help, and the Thesaurus were the most valuable aspects of “Composición: Proceso y Síntesis.” However, all of the tools had weaknesses, according to the users of the program. The Spell Check, for example, was considered to be useful because, as Hannah said, "it makes me realize the mistakes I made and try not to do it next time." But it did not provide immediate grammatical feedback, which from the participants' perspectives, was fundamental in order to improve their writing skills in Spanish.

The capabilities of the Special Character Help were also recognized and valued in the sense that this tool improved the final appearance of the document. However, students did not like the inconvenience they felt in the process they had to go through each time they needed to type a special character. They definitely thought that this feature of the program should be simplified. As an aside, the investigator is aware that the participants' interest in this tool demonstrates their lack of knowledge concerning other word 
processing programs. Such commercial software has, in fact, the very same characteristics (regarding the incorporation of accent marks, and other special symbols) as "Composición: Proceso y Síntesis," but none of the informants seemed to be aware of this.

The Thesaurus was thought to be one of the most useful resources of the program. The researcher perceived a clear effort from the students to incorporate new vocabulary into their compositions. Nonetheless, as a consequence of the learners' recognition of their own vocabulary, they all felt that a bilingual dictionary needed to be incorporated.

Early in the study, the researcher became aware that the students had a tendency to omit the pre-writing stage in the writing process. As Jane explained:

[In] Spanish 3 [...] we only had two compositions. The first one was actually very easy $[\ldots]$ so I just went straight down and wrote it from my mind. The second one was more factual, $[\ldots]$ but I didn't really do any pre-writing or brainstorming.

All sources of data indicate that the students felt that the greatest strength of the program was the editing tools. Perhaps for this reason they attached little value to the generation of ideas that came about through the use of the Invent tool. Notably, however, their attitudes toward brainstorming did become more positive as the study progressed. For this reason I have the impression that students' prior writing habits (rather productcentered, as implied by previous data) have very much influenced their first perceptions of "Composición: Proceso y Síntesis."

As the participants became increasingly familiar with the program and learned more about its features and capabilities, they began to appreciate the pre-writing tools offered, such is the Invent section. Students' comments and reactions revealed a general 
change in their writing habits from the moment they began to use the software for their compositions. As Michelle explained: "It is easier now with the brainstorming thing."

Data analysis seems to suggest that students were accustomed to a more traditional grammar and product- centered writing instruction from their previous classes. They attributed little importance, prior to the use of this software, to the pre-writing stage.

\section{Factors Affecting Participants' Perceptions of "Composición” Proceso y Sintesis"}

Three major factors appear to affect participants' perceptions and attitudes toward the "Composición: Proceso y Síntesis:" their previous contact with computers, the two training sessions held, and the instructional setting where the project took place. Based on informants' responses and observations, both prior contact with computers and the training sessions designed to familiarize students with the software turned out to play a very important role in the development of this project. Questionnaires and interviews confirmed that the students were already familiar with the use of computers. This previous contact apparently influenced the students' positive attitude and interest in using computers in the foreign language classroom. Eric's words support this: "I think I've used computers for everything, so why not for foreign languages?"

There were two major sites where the present study took place: the computerequipped classroom, and the CALL Lab. Jane's remarks summarize the general feelings of the students regarding the instructional setting:

I was kind of happy that we were not starting a normal, typical education I guess. And I like the fact that we use the software, but it's rather constraining too 'cause we have to go to the lab to use it. I don't like that part too much. 
The analysis of the data shows that participants in general, with the exception of Rob, apparently enjoyed having class in the computer-equipped classroom. It was the rather untypical education, as Jane stated above, and the fact, as Amy explains, of getting a "break from using the book constantly" that they appreciated most about those classes. However, the excitement shown for the use of this facility was not shared when having to go to the CALL Lab to write and print their compositions. There was a general agreement that the access to the CALL Lab was too limited, since its hours were much more restricted than other sites on campus. This major constraint had a negative effect on the participants, as shown by Michelle's words:

I think it could be better if you could [...] install the program on your own computer, and use the program at your own convenience. And then everybody would have a better attitude about it too, 'cause they wouldn't have to worry about well, I have to work tomorrow, and I have to come today and do it. I think that would be better 'cause I think it's a helpful program.

Finally, it should be noted that some technical difficulties took place in the beginning of this study. Fortunately, they were solved and apparently, as deduced from the data, they did not have a great influence on the final result of the study. In this sense, it seems that most of the participants were not especially concerned with mechanical failure. Instead, they recognized it as a reality associated with the use of computers both inside and outside the classroom. John echoes participants' attitude in this respect:

There has been difficulties as far as the program is not running, crashing, it's difficult to print out, you know [...] [but] I did anticipate the technical difficulties that always come with computers. 


\section{Conclusion}

The present study, as shown by the information gathered, appear to confirm the rather positive influence and acceptance that writing assistant software has when introduced in the foreign language classroom. The novelty of such a tool, together with its interactive design and its ability to display information at the users' own pace, seemed to attract participants' interest. It also invited them to take more risks in the writing class. However, since only twelve subjects (six main and six secondary informants) participated in this study, my conclusions should be interpreted as tentative until further research is done.

Students' showed a special interest in the editing tools. They highly valued their features, however, they also perceived their limitations, which detracted from the overall appreciation of "Composición: Proceso y Síntesis." The publisher may want to consider the results of the present study in the event the program is revised and expanded.

Concerning the issue raised by the influence that instructional setting had on participants' perception, one possibility of further inquiry is the need to establish what could have happened if the participants would have been given a copy of "Composición: Proceso y Síntesis" to be loaded on their machines. Many remarks were made by informants in this respect. As Eric commented, "I would [...] give it an A. And I think the only reason why people would give it less than that is for the inconvenience of going to $[\ldots]$ the lab." Since this writing assistant software is on the market, future investigations could focus their attention on the comparison of the way results might be altered increasing the accessibility to the program. 
The positive attitude the students had towards computer-integration in the foreign language class seems to have been influenced by the previous exposure, both inside and outside class, that the participants had. As a result of the frequent contact with computers that West Virginia University students have, participants did not hesitate to involve themselves in the project, and/or use software programs to implement their writing skills in Spanish. The differences among my results and those obtained in previous research (e.g. Burnett 1999) might have to do not only with this previous exposure to computers, but also to the two training sessions held to familiarize students with the program. In order to investigate further the importance played by the exposure factor, one might replicate the present project in a country (e.g. Spain), where students do not have as much access to this sort of technology as they do here in the United States, and see what their reactions and perceptions are.

Regardless, however, the data do demonstrate clearly the positive attitude that students in this study had towards the application of computer-based technology to the teaching of writing in Spanish as a foreign language. 


\section{WORKS CITED}

Albert, L. "Process versus Product: The Variable Effects on L1 and L2 Writing Quality and Apprehension, and L2 Grammatical Accuracy." Thesis. West Virginia University, 1993.

Allessi, S., and Trollip, S. Computer-Based Instruction: Methods and Development. New Jersey: Englewood Cliffs, 1991.

Amores, M. "The Nature of Peer-Editing in the Foreign Language Composition Class." Diss. The Pennsylvania State University, 1996.

Armstrong, K. and Yetter-Vassot, C. "Transforming Teaching through Technology." Foreign Language Annals 74 (1994): 477-485.

Barnett, M. "Writing as a Process.” The French Review 63 (October 1989): 31-44.

Bazillion, R. J. and Braun, C. "Teaching on the Web and in the Studio Classroom." Syllabus (April 1998): 37-39.

Bloor, M. "Techniques of Validation in Qualitative Research: A Critical Commentary." Context and Method in Qualitative Research. Ed. Gale Miller and Robert Dingwall. London: Sage Publications, 1997.

Brown, I. "Internet Treasure Hunts -A Treasure of an Activity for Students Learning English." The Internet TESL Journal 1999. 30 Jan. 1999. <www.aitech.ac.jp/ iteslj/lessons/Brown-TreasureHunts.html>

Burnett, J. "Classroom-Management-Classroom Survival: One Teacher's Story of Constructing Practice in a Computer-Equipped Foreign Language Classroom." Foreign Language Annals 32 (1999): 279-294.

Bush, M. "Implementing Technology for Language Learning." Technology-Enhanced Language Learning. Ed. Michael D. Bush. Chicago: National Textbook Company, 1997.

Canada, K., and Brusca, F. "The Technological Gap: Evidence and Recommendations for Educators and Computer-Based Instruction Designers.” 2000. 6 May. 2000. <http://www.kingsfield.com/frnk/etrd.html >

CNN Interactive. "Gore Pledges \$50 million for Next Generation Internet." 1998. 14 Apr.1998. <http://cnn.com/TECH/computing/9804/14/internet2/index.html>

CNN Interactive. "Vice President Wants more Internet Access for Schools." 1998. 29 Apr. 1998. <http://cnn.com/TECH/computing/9804/14/internet2/index.html> 
Connor, U. "Research Frontiers in Writing Analysis." TESOL Quarterly 21 (1987): 677691.

Cumming, A. "Writing Expertise and Second Language Proficiency." Language Learning 39 (1989): 81-141.

Cuban, L. Teachers and Machines: The Classroom Use of Technology since 1920. New York: Teachers College Press, 1986.

Denzin, N. The Research Act: A Theoretical Introduction to Sociological Methods. New Jersey: Englewoods Cliffs, NJ: Prentice Hall, 1989.

Denver, J. “Take Me Home.” Poems, Prayers, and Promises. RCA Records, 1988.

Foester, S., Lambright, A., Alonso-Pinto, F. Punto y Aparte. Boston: McGraw-Hill, 1999.

Gagné, R. The Conditions of Learning. New York: Holt, Rinehart and Winston, 1985.

Garret, N. "Technology in the Service of Language Learning: Trends and Issues." The Modern Language Journal 75 (1991): 74-88.

Green, A. "A Beginner's Guide to the Internet in the Foreign Language Classroom with Focus on the World Wide Web." Foreign Language Annals 30 (1997): 253264.

Gonglewski, M. "Linking the Internet to the National Standards for Foreign Language Learning." Foreign Language Annals 32 (1999): 348-362.

Hairston, M. "The Winds of Change: Thomas Kuhn and the Revolution in Teaching of Writing." College Composition and Communication 33 (February 1982): 76-88.

Hamer, B. "Clinton's Bridge Across the Digital Divide.” CNN Interactive. 2000.

4 Feb. 2000.

<http://cnn.com/2000/TECH/computing/02/04/clintonbridging.divide.idg/index.html〉

Harris, J. "Student Writers and Word Processing." College Composition and Communication 36 (1985): 323-330.

Hawkins, J. "Computers and Girls: Rethinking the Issues." Sex Roles 13 (1985): 165180.

Heidberg, J. "Rethinking the Selection of Learning Technologies." Australian Journal of Educational Technology 5 (1989): 132-160.

Hooper, S. "Authorware 3.5: Multimedia Authoring for Instructional Materials." Syllabus (February 1997): 38-45. 
Janello, P. "Software Evaluation for the Teacher of the English Language Arts." ERIC Digest 1984. 9 Jan 1999. <http://www.ed.gov/databases/ERIC_Digests/ed250697.html>

Jia, G., Winser, B., Chewng, W. "Guidelines in Selecting Listening Software Packages for School Students." 1996. 9 Jan. 1999 <http://www.spirit.com.au/ACEC96/papers/jia.htm>

Kesner-Bland, S., Noblitt, J., Armington, S., Gay, G. "The Naïve Lexical Hypothesis: Evidence for Computer-Assisted Language Learning." The Modern Language Journal 74 (1990): 440-450.

Kinzer, C. and Leu, D. J. "The Challenge of Change: Exploring Literacy and Learning in Electronic Environment.” Language Arts 74 (February 1997): 126-135.

Kost, C. "Enhancing Communicative Language Skills through Effective Use of the World Wide Web in the Foreign Language Classroom." Foreign Language Annals 32 (1999): 309-320.

Kroll, B. "Teaching Writing in the ESL Context." Teaching English as a Second Language. Ed. Marianne Celce-Murcia. Boston: Heinle \& Heinle, 1991.

LaFrez, O. and Friedman, J. "Computers Don't Change Education, Teachers Do." Harvard Educational Review 59 (1989): 222-225.

Lawley, E. "Computers and the Communication of Gender." 1993. 6 May. 2000. $\langle\underline{\text { http://www.itcs.com/elawley/gender.html }>}$

Lay, N. "Composing Processes of Adult ESL Learners: A Case Study.” TESOL Quarterly 16 (1982): 406

LeCompte, M. and Goetz, J. "Problems of Reliability and Validity in Ethnographic Research.” Review of Educational Research 52 (1982): 31-60.

Lee, J. and VanPatten, B. "On Roles and Tasks." Making Communicative Language Teaching Happen. New York: McGraw-Hill: 1995.

Lincoln, Y. and Guba, E. Naturalistic Inquiry. Beverly Hills, CA: Sage Publications, Inc., 1985.

Lixl-Purcell, A. "Foreign Language Education with Multimedia Technologies." 1999. 3 Oct. 1999. <www.uncg.edu/ lixlpurc/publications/MLAtech.html>

Maddox, A. "Implementing School Technology: Calling on Teachers." Technology Connection 64 (1997): 12-13. 
Magid, L. "U.S. Could Learn from Europe's Wiring of Schools." CNN Interactive 1998. 30 Jan. 1998. <http://cnn.com/TECH/computing/9801/30/magid.netday/>

Maule, W. "The Network Classroom.” Interpersonal Computing and Technology: An Electronic Journal for the $21^{\text {st }}$ Century 1 (1993): 10-24.

Marshall, C. and Rossman, G. Designing Qualitative Research. New York: Sage Publications, 1989.

Moyer, K. "The Price of Education.” Converge Magazine. 1999. 25 Feb. 2000. <www.convergemag.com/publications/CNVGNOV99/2legistators/2legistators.shtm>

Moskowitz, R. "Breaking Through Computer Anxiety." 1995. 4 Apr. 2000. <http://www.smartbiz.com/sbs/arts/mos47.html>

Murray, D. "Write before Writing." College Composition and Communication. 29 (1978): 375-381.

Owen, T. "Poems that Change the World: Canada's Wired Writers." English Journal (October 1995): 48-52.

Oppenheimer, T. "The Computer Delusion.” The Atlantic Monthly 280 (1997): 45-62 25 Feb.2000. <www.theatlantic.com/issues/97jul/computer.htm>

Pearlman, R. “Technology's Role in Restructuring Schools.” Electronic Learning 8 (1989): 8-10.

Pusack, P. and Otto, S. "Taking Control of Multimedia.” Technology Enhanced Language Learning. Ed. Michael D. Bush. Chicago: National Textbook Company, 1997.

Reed, W. "The Effects of Computer-Based Writing Instruction and Mode of Discourse on Writers' Performance and Anxieties." Computers in Human Behavior 6 (1990): 211221.

Roblyer, M. and Edwards, J. Integrating Educational Technology into Teaching. Englewood Cliffs, NJ: Prentice Hall, 2000.

Ryan, K. “Teaching with Computers.” Language Teacher Online 1997. 29 Aug. 1997. <www.langue.hyper.chubu.ac.jp/jalt/pub/ttt/97/aun/ryan.html>

Scardamalia, M. and Bereiter, C. "Research on Written Composition." Handbook of Research on Teaching. Ed. M.C. Wittrock. New York: Macmillan, 1982. 
Selwyn, N. "Resisting the Technological Imperative: Issues in Researching the 'Effectiveness' of Technology in Education.” 1999. 3 Feb. 1999.

<www.computed.coe.wayne.edu/Vol5/Selvyns.html>

Shashaani, L. "Gender-Based Differences in Attitudes toward Computers." Computers and Education 20 (1993): 169-181.

Shucart, S. "Where in CALL is Carmen Sandiego? An Evaluative Software Review." Language Teacher Online 1998. 9 Jan. 1999. <www.langue.hyper.chubu.ac.jp/jalt/pub/tlt/98/feb/shucart.html >

Singhal, M. "The Internet and the Foreign Language Education: Benefits and Changes." The Internet TESL Journal 1999. 9 Nov. 1999. <www.aitech.ac.jo/ iteslj/Articles/singhal- internet.html>

Spack, R. "Invention Strategies and the ESL College Composition Student." TESOL Quarterly 18 (1984): 649-670.

Standards for Foreign Language Learning in the $21^{\text {st }}$ Century. Lawrence, KS: Allen Press, Inc., 1999.

Stevens, V. "A Direction for C.A.L.L: From Behavioristic to Humanistic Courseware." Teaching Languages with Computers. Ed. Martha Pennington. La Jolla: Athelstan, 1989.

Summers, J. "Effect of Interactivity upon Student Achievement, Completion Intervals, and Affective Perceptions." Journal of Educational Technology Systems 19 (19901991): 53-57.

Sylverman, D. "The Logics of Qualitative Research." Context and Method in Qualitative

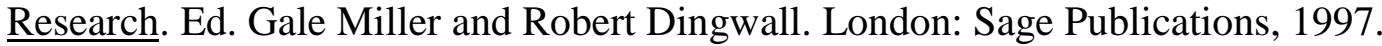

Swan, K. \& Mitrani, M. "The Changing Nature of Teaching and Learning in ComputerBased Classrooms." Journal of Research on Computing in Education 26 (1993): 4054.

Terrell, T., Andrade, M., Egasse, J., Muñoz, E. Dos Mundos. Boston: McGraw-Hill, 1998.

Turkle, S. The Second Self: Computers and the Human Spirit. New York: Simon \& Schuster, 1984.

Valdés, G., Dvorak, T., Hannum, T. Composición: Proceso y Síntesis. CD-ROM. Boston: McGraw-Hill, 1999.

Walz, J. "Meeting Standards for Foreign Language Learning with World Wide Web Activities." Foreign Language Annals 31 (1998): 103-114. 
Warschauer, M. "Motivational Aspects of Using Computers for Writing and Communication." 1996. 4 Apr. 2000.

<http://www.lll.hawaii.edu/nflrc/NetWorks/NW1.html>

West Virginia University. 1999-2001 Undergraduate Catalog. Morgantown: West Virginia University, 1999.

Wilcox, K. and Jensen, M. "Computer Use in the Science Classroom: Proceed with Caution.” JCST (February 1997): 258-264.

Yukio, H. "Writing to Improve Analytical and Organizational Skills." The Language Teacher Online 199820 Feb. 1999.

<http://langue.hyper.chubu.as.jp/jalt/pub/tlt/98/dec/hirayanagi.html>

Zamel, V. "Writing: The Process of Discovery Meaning." TESOL Quarterly 16 (1982): 195-209.

Zamel, V. "The Composing Process of Advanced ESL Students: Six Case Studies." TESOL Quarterly 17 (1983): 165-187.

Zerh, A. “Computer Classes Aren’t Just for Boys Anymore.” 1998. 6 May. 2000. <http://edweek.org/ew/vol-17/19girls.h17> 
APPENDICES 


\section{APPENDIX 1:}

SPANISH 4 SYLLABUS 


\section{Appendix 1 \\ SPANISH 4 \\ Intermediate Spanish (M W F) \\ Spring Semester 2000}

Instructor:

Section:

Office Hours:

Telephone:

Required texts: Foerster, Lambright \& Alfonso-Pinto. Punto y Aparte. Boston, MA: McGraw-Hill, 1999.

Course description and goals: Spanish 4 plays a dual role in the Spanish curriculum: it is the capstone course in the initial series of languages courses (Spanish 1-4), and it is also the preparatory course for more advanced study. As such, its goals are two-fold: to help you acquire the ability to use what you have learned by focusing on seven essential communicative functions in Spanish (describing, comparing, reacting and recommending, narrating in the past, talking about likes and dislikes, hypothesizing, and talking about the future), and to help you achieve greater cohesion in your speaking and writing abilities. Further, this course will give you an opportunity to apply these skills as you learn more about Hispanic cultures through authentic sources. Specifically, the course will center around short readings selected from the textbook, accompanied by a variety of preparatory and follow-up activities.

Course Objectives: Upon successful completion of this course, you should be able to:

1) SPEAK Spanish well enough to describe, narrate, react and recommend, compare, talk about the future, and hypothesize about most familiar topics and about the resources discussed in this course.

2) COMPREHEND spoken Spanish with sufficient ability to grasp the main idea and most of the supporting details in short conversations and in more extended and formalized presentations--both prepared and spontaneous--that relate to topics with which you have some degree of familiarity.

3) READ AND UNDERSTAND the main idea and most details of both edited and non-edited material, including both literal and figurative meaning.

4) WRITE coherent sentences, paragraphs, short essays and opinion pieces on familiar topics, and respond in writing to the ideas and opinions of others.

5) RECOGNIZE that cultural differences do exist and that learning a language enables a person to better understand and interact with the people who use the language natively. 
Course Grade: Your final grade in Spanish 4 will be determined based on the following components.

Course requirements and Evaluation

Class preparation and participation

Chapter exams

Quizzes

Homework

Essays

Oral exams

Final exam

Explanation of grades:
Grade equivalents*

$15 \%$

$20 \%$

$10 \%$

$5 \%$

$15 \%$

$15 \%$

$20 \%$

$$
90-100 \quad \text { A }
$$

$80-89 \quad$ B

$70-79 \quad$ C

$60-69 \quad \mathrm{D}$

59 and below $\mathrm{F}$

$* \mathrm{~A}=$ excellent (given only to students of superior ability and attainment)

$\mathrm{B}=$ good (given only to students who are well above average, but not in the highest group)

$\mathrm{C}=$ fair (average for undergraduate students)

$\mathrm{D}=$ poor but passing (cannot be counted for graduate credit)

$\mathrm{F}=$ failure

I = incomplete

$\mathrm{W}=$ withdrawal from a course before the date specified in the University Calendar (Additional components of the WVU grading system can be found in the Undergraduate Bulletin)

Please note: The grade of Incomplete is given only in those instances where an examination has been missed or another major course requirement has not been met as a result of an excused absence. The grade is NOT to be assigned in lieu of an F or when the performance throughout the semester has been generally unsatisfactory.

Class preparation and participation (15\%): Your involvement in classroom discussions and activities will be evaluated by your instructor. Being prepared for and participating in class activities is one of the most important means of attaining the goals of the course. Therefore, this component takes into account a number of variables including but not limited to: 1) your actual presence in the classroom, 2) your use of Spanish, 3) your willingness and ability to participate, 4) your cooperation in group and pair work, and 5) your respect and attitude towards the class and your peers. Find attached the criteria used by your instructor to determine your participation grade.

Participation grades will be given every week starting at the end of the second week for a total of 13 grades.

Exams (20\%): There will be three chapter examinations in the course. Exam 1 will cover material presented in the preliminary chapter and chapter 1 . Exam 2 will cover chapters 2 and 3. Exam 3 will cover chapter 4 and 5. There will be no exam for Chapter 6 as this material will be included on the Final Exam. These exams will test a variety of skills and information, including reading and writing sections. No make-ups without documented excuse. Lesson exams are not curved. 
Quizzes (10\%): For each chapter (with the exception of chapter 6), you will have a vocabulary quiz on the words and expressions introduced in the unit. In addition, several unannounced quizzes will be given during the semester. Topics will include the content of homework assignments, readings and class discussions, etc.

Homework (5\%): You will be responsible for the completion of the homework exercises as indicated by the instructor. Failure to do so will result in a grade of 0 on the assignment. Homework will NOT be accepted late.

Essays (15\%): At the end of chapters 1 and 3 you will be asked to react to the material in those sections through an essay. For each assigned composition, you will write three drafts. The first draft of both compositions will be peer edited using a checklist provided by your teacher. When turning in the second draft be sure to attach the first draft, your reviewer's comments and your own comments about the reviewer along with the second draft. The second and third drafts of your compositions will not be handed back corrected. In the margins or at the end of the paper, you will see suggestions about organization and style. Also you will note errors underlined, but not corrected. See your instructor about any corrections or suggestions of which you are not absolutely sure, before you hand in your next version. Your grade on the paper will be determined by combining your scores on the second and third drafts. The second draft of your composition will account for $40 \%$ of the grade, and the third draft, $60 \%$ of the grade. Class time will be allotted for you to begin work on them, though due to the extensive writing process you will finish them at home. While brainstorming of ideas and discussion with classmates are encouraged, work is, nonetheless, to be an individual effort. Compositions that have obviously been written in collaboration with tutors or native-speakers will not receive credit. All drafts and final versions must be doublespaced, typed, with your name, the composition title and the draft number at the top of the first page of each version. Remember always to hand in your rough drafts and preparatory work with the final version. Final versions of compositions are due as indicated in the syllabus; the due dates for the different rewrites of your essays, however, will be assigned by your instructor. The grading criteria used to evaluate the essays are attached.

Oral exams (15\%): The oral exam will consist of cultural presentations, done individually or in pairs, about a variety of topics, including those you studied in chapters 1-6 with the exception of chapter 5. The exam will last approximately 10-20 minutes, and will be scheduled by your instructor throughout the semester. There are NO makeups. See attached for grading criteria for oral exam.

Final exam (20\%): The final examination is cumulative. These exams will include both reading and writing sections, and will likely involve a reading selection that you have not seen previously so that you can demonstrate your ability to apply the skills you have learned. Considerable emphasis will be placed on your ability to derive meaning from a text and to answer questions based on the content. This final written exam will be administered during Final Exam week. The date will be announced later in the semester, as well as the date for petitions for overload conflicts. 


\section{Attendance Policy}

Regular class attendance is required for successful completion of the course. If you are absent one day during a week, 4 points will be subtracted from your participation grade of that week; 7 points will be deducted if you are absent twice. If an absence penalty results in a negative score, a rating of zero will be recorded. Likewise, if you are absent all three days during the week, your participation will also receive a rating of zero. Work is accepted only on or before the due dates specified in the syllabus. If you are absent from class, you are responsible for making arrangements to have your work handed in on the due date, and for informing yourself of the information covered in class during the period of your absence. No other make up work will be assigned or accepted. No extra credit work is permitted. If a regularly scheduled exam is missed due to an authorized university activity, you will be given an opportunity to make up the exam, provided that an official written excuse from a coach or other university official is presented to the instructor within 10 days of the absence.

In the case of chronic illness or personal emergencies requiring prolonged or frequent absences, the student should withdraw from this course and repeat it when the circumstances allow fulfillment of course requirements.

\section{Mutual expectations}

West Virginia University is committed to social justice and academic honesty. I concur with that commitment and expect to foster a nurturing learning environment based upon open communication, mutual respect, and non-discrimination. Our University does not discriminate on the basis of sex, race, age, veteran status, disability, sexual orientation, color, national origin or religion. Any suggestions as to how to further such an environment will be appreciated and given serious consideration. The class will be conducted in accordance with the University's policies and procedures as contained in the WVU Student Handbook (The Mountie), which are expected to apply throughout the course.

If you are a person with a disability and anticipate needing any type of accommodation in order to participate in this class, please advise me and make appropriate arrangements with Disability Services (293-6700). 


\section{Syllabus}

Dates

Jan. 10

$12-19$

[Jan. 17

21-

Feb. 2

4

7-18

21-

\# 1 due

Mar. 3

6

$8-20$

$22-24$

\# 2 due

Lesson

Introducción al curso

\section{CAPÍTULO PRELIMINAR}

Para empezar

Martin Luther King's Birthday Recess-NO CLASS]

CAPÍTULO 1

Perspectivas: Percepciones e impresiones

Ensayo \# 1, pág. 36

Quiz \# 1

EXAMEN CAPÍTULOS Para empezar \& 1

CAPÍTULO 2

Conexiones: ¿Qué importancia tienen

nuestras raíces?

Quiz \# 2

CAPITULO 3

Relaciones sentimentales: ¿Cómo influyen

en nuestra vida los demás?

Ensayo \# 2, pág. 86

Quiz \# 3

EXAMEN CAPÍTULOS $2 \& 3$

CAPÍTULO 4

El trabajo y el ocio: ¿Cómo se relaja $U d$.?

Quiz \# 4

CAPÍTULO 5

Ensayo

El mundo actual: ¿Cómo influyen en

nosotros los problemas del mundo?

Quiz \# 5

25-Apr. 2 Spring Break Recess-NO CLASS

3-10 CAPÍTULO 5 (cont.)

12

EXAMEN CAPÍTULOS 4 \& 5

14-28 CAPÍTULO 6

El nuevo milenio: ¿Qué nos espera en el futuro?

[Ap. $21 \quad$ Easter Recess-NO CLASS] 


\section{Class Participation Grading Criteria}

\section{Description}

\section{Rating}

During the past week, this student...

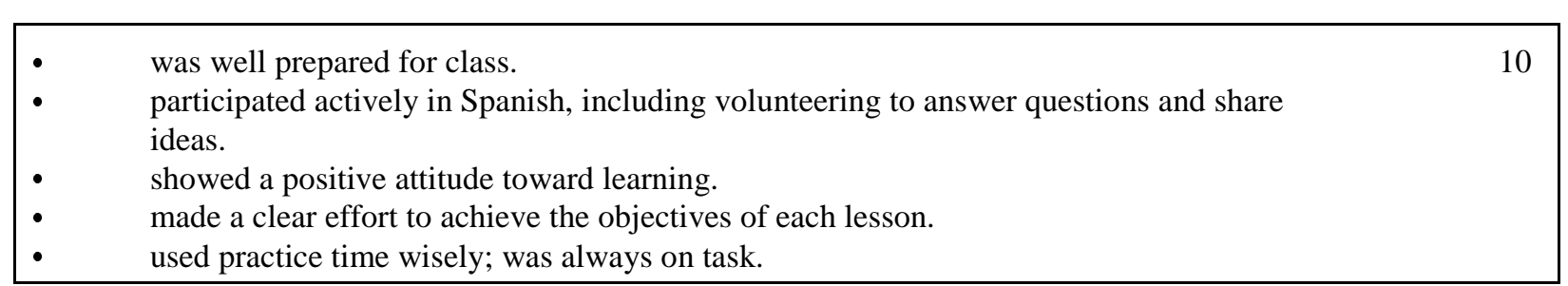

- $\quad$ was well prepared for class.

- $\quad$ participated in Spanish, although sometimes passively.

- $\quad$ showed a positive attitude toward learning.

- $\quad$ made an effort to achieve lesson objectives, although there is room for improvement.

- $\quad$ stayed on task and used practice time wisely.
- was somewhat prepared for class. showed more passive than active participation in class. had a less-than-positive attitude toward learning. made a minimal effort toward achieving lesson objectives; there is significant room for improvement.
- $\quad$ tended to stray from the task at hand; could make better use of practice time

\begin{tabular}{|c|c|c|}
\hline $\begin{array}{l}\bullet \\
\bullet \\
\bullet\end{array}$ & $\begin{array}{l}\text { was not well prepared for class. } \\
\text { was a passive or non-participant in class activities. } \\
\text { showed a negative attitude toward learning. } \\
\text { made little to no effort toward achieving lesson objectives; immediate improvement is } \\
\text { necessary. } \\
\text { was easily distracted off task; often wasted practice time. }\end{array}$ & $1-3$ \\
\hline$\bullet$ & $\begin{array}{l}\text { was absent all three days; thus participation is unratable. } \\
\text { or } \\
\text { behaved in a disrespectful, distracting, or otherwise unacceptable manner (sleeping in } \\
\text { class, reading the newspaper, leaving the room frequently or for lengthy periods of } \\
\text { time, etc.). } \\
\text { made it difficult for others in the class to learn. }\end{array}$ & 0 \\
\hline
\end{tabular}

\section{Penalty for absences}

Because you can only participate when you are in class, the above rating can only reflect your performance on the days when you are in attendance. From this score, 4 points will be subtracted if you have been absent one day during the week; 7 points will be deducted if you have been absent twice. If an absence penalty results in a negative score, a rating of zero will be recorded. Likewise, if you are absent all three days during the week, your participation will also receive a rating of zero. 


\section{Grading Criteria for Compositions}

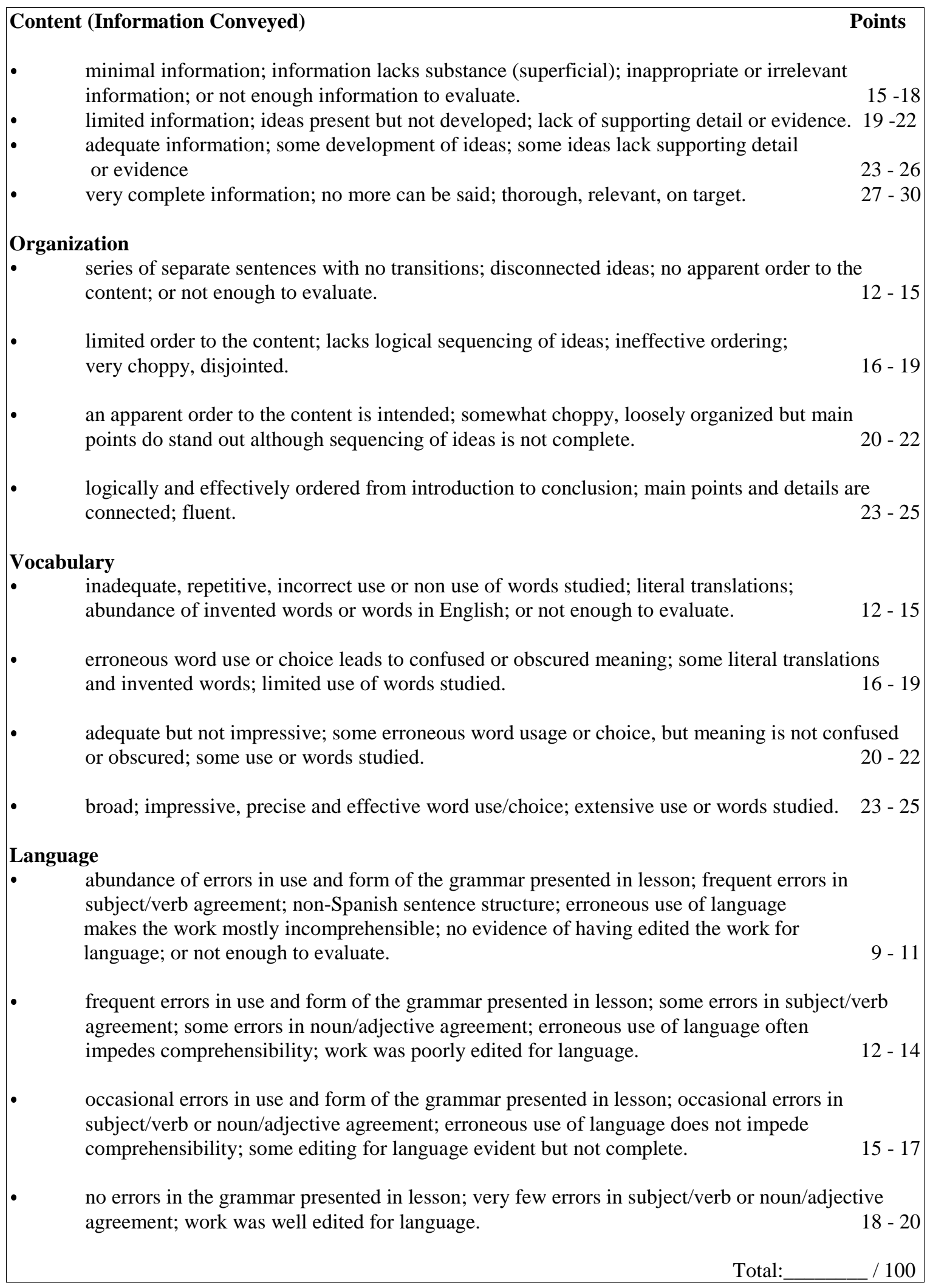




\section{Grading Criteria for Presentations}

Nombre:

Clase:

Nota: $\quad / 50$

Fecha:

Examen:

Comentarios:

\section{Comprehensibility}

1. Completely comprehensible to native speakers of Spanish. 12

2. Mostly comprehensible but with some errors, sometimes slow and simple.

3. Frequent errors in use of language sometimes impede comprehensibility.

4. Mostly incomprehensible to native speakers of Spanish. 5

\section{Content}

1. Well developed ideas, clear, to the point. 12

2. Ideas mostly well developed, fairly clear and relevant. 10

3. Ideas present but not well developed. 8

4. Minimal and/or irrelevant information. 5

\section{Vocabulary}

1. Rich and extensive vocabulary; very accurate usage.

2. Occasionally lacks basic words; generally adequate for situation.

3. Mostly inaccurate or inadequate.

\section{Fluency}

1. Speech generally natural and continuous; no unnatural pauses. 8

2. Some definite stumbling, but manages to rephrase or continue. 7

3. Speech frequently hesitant and jerky; sentences may be left uncompleted.

4. Speech halting and fragmentary; long, unnatural pauses or utterances.

\section{Pronunciation}

1. Generally good, accurate stress. $\quad 8$

2. Rather good but with some striking non-Spanish sounds. 6

3. Generally poor, use of non-Spanish vowels and consonants, incorrect stress. 


\section{APPENDIX 2:}

NURIA'S SYLLABUS 


\section{Appendix 2 \\ SPANISH 4 \\ Intermediate Spanish (M W F) \\ Spring Semester 2000}

Instructor:_NURIA GAGO Email: pucelana_75@yahoo.com Section: 007

Office Hours: To be announced.

Telephone:

293-5121 EXT: 5531

Required texts: Foerster, Lambright \& Alfonso-Pinto. Punto y Aparte. Boston, MA: McGraw-Hill, 1999.

Course description and goals: Spanish 4 plays a dual role in the Spanish curriculum: it is the capstone course in the initial series of languages courses (Spanish 1-4), and it is also the preparatory course for more advanced study. As such, its goals are two-fold: to help you acquire the ability to use what you have learned by focusing on seven essential communicative functions in Spanish (describing, comparing, reacting and recommending, narrating in the past, talking about likes and dislikes, hypothesizing, and talking about the future), and to help you achieve greater cohesion in your speaking and writing abilities. Further, this course will give you an opportunity to apply these skills as you learn more about Hispanic cultures through authentic sources. Specifically, the course will center around short readings selected from the textbook, accompanied by a variety of preparatory and follow-up activities.

Course Objectives: Upon successful completion of this course, you should be able to:

1) SPEAK Spanish well enough to describe, narrate, react and recommend, compare, talk about the future, and hypothesize about most familiar topics and about the resources discussed in this course.

2) COMPREHEND spoken Spanish with sufficient ability to grasp the main idea and most of the supporting details in short conversations and in more extended and formalized presentations--both prepared and spontaneous--that relate to topics with which you have some degree of familiarity.

3) READ AND UNDERSTAND the main idea and most details of both edited and non-edited material, including both literal and figurative meaning.

4) WRITE coherent sentences, paragraphs, short essays and opinion pieces on familiar topics, and respond in writing to the ideas and opinions of others.

5) RECOGNIZE that cultural differences do exist and that learning a language enables a person to better understand and interact with the people who use the language natively. 
Course Grade: Your final grade in Spanish 4 will be determined based on the following components.

Course requirements and Evaluation

Class preparation and participation

Chapter exams

Quizzes

Homework

Essays

Oral exams

Final exam

Explanation of grades:
Grade equivalents*

$15 \%$

$20 \%$

$10 \%$

$5 \%$

$15 \%$

$15 \%$

$20 \%$

$$
90-100 \quad \text { A }
$$

$80-89 \quad$ B

$70-79 \quad$ C

$60-69 \quad \mathrm{D}$

59 and below $\mathrm{F}$

$* \mathrm{~A}=$ excellent (given only to students of superior ability and attainment)

$\mathrm{B}=$ good (given only to students who are well above average, but not in the highest group)

$\mathrm{C}=$ fair (average for undergraduate students)

$\mathrm{D}=$ poor but passing (cannot be counted for graduate credit)

$\mathrm{F}=$ failure

I = incomplete

$\mathrm{W}=$ withdrawal from a course before the date specified in the University Calendar (Additional components of the WVU grading system can be found in the Undergraduate Bulletin)

Please note: The grade of Incomplete is given only in those instances where an examination has been missed or another major course requirement has not been met as a result of an excused absence. The grade is NOT to be assigned in lieu of an F or when the performance throughout the semester has been generally unsatisfactory.

Class preparation and participation (15\%): Your involvement in classroom discussions and activities will be evaluated by your instructor. Being prepared for and participating in class activities is one of the most important means of attaining the goals of the course. Therefore, this component takes into account a number of variables including but not limited to: 1) your actual presence in the classroom, 2) your use of Spanish, 3) your willingness and ability to participate, 4) your cooperation in group and pair work, and 5) your respect and attitude towards the class and your peers. Find attached the criteria used by your instructor to determine your participation grade. Participation grades will be given every week starting at the end of the second week for a total of 13 grades.

Exams (20\%): There will be three chapter examinations in the course. Exam 1 will cover material presented in the preliminary chapter and chapter 1 . Exam 2 will cover chapters 2 and 3. Exam 3 will cover chapter 4 . There will be no exam for Chapter 6 as this material will be included on the Final Exam. These exams will test a variety of skills and information, including reading and writing sections. No make-ups without documented excuse. Lesson exams are not curved. 
Quizzes (10\%): For each chapter (with the exception of chapter 5), you will have a vocabulary quiz on the words and expressions introduced in the unit. In addition, several unannounced quizzes will be given during the semester. Topics will include the content of homework assignments, readings and class discussions, etc.

Homework (5\%): You will be responsible for the completion of the homework exercises as indicated by the instructor. Failure to do so will result in a grade of 0 on the assignment. Homework will NOT be accepted late.

Essays (15\%): At the end of chapters 1 and 3 you will be asked to react to the material in those sections through an essay. For each assigned composition, you will write three drafts. The first draft of both compositions will be peer edited using a checklist provided by your teacher. When turning in the second draft be sure to attach the first draft, your reviewer's comments and your own comments about the reviewer along with the second draft. The second and third drafts of your compositions will not be handed back corrected. In the margins or at the end of the paper, you will see suggestions about organization and style. Also you will note errors underlined, but not corrected. See your instructor about any corrections or suggestions of which you are not absolutely sure, before you hand in your next version. Your grade on the paper will be determined by combining your scores on the second and third drafts. The second draft of your composition will account for $40 \%$ of the grade, and the third draft, $60 \%$ of the grade. Class time will be allotted for you to begin work on them, though due to the extensive writing process you will finish them at home. While brainstorming of ideas and discussion with classmates are encouraged, work is, nonetheless, to be an individual effort. Compositions that have obviously been written in collaboration with tutors or native-speakers will not receive credit. All drafts and final versions must be doublespaced, typed, with your name, the composition title and the draft number at the top of the first page of each version. Remember always to hand in your rough drafts and preparatory work with the final version. Final versions of compositions are due as indicated in the syllabus; the due dates for the different rewrites of your essays, however, will be assigned by your instructor. The grading criteria used to evaluate the essays are attached.

Oral exams (15\%): The oral exam will consist of cultural presentations, done individually or in pairs, about a variety of topics, including those you studied in chapters 1-6 with the exception of chapter 5. The exam will last approximately 10-20 minutes, and will be scheduled by your instructor throughout the semester. There are NO makeups. See attached for grading criteria for oral exam.

Final exam (20\%): The final examination is cumulative. These exams will include both reading and writing sections, and will likely involve a reading selection that you have not seen previously so that you can demonstrate your ability to apply the skills you have learned. Considerable emphasis will be placed on your ability to derive meaning from a text and to answer questions based on the content. This final written exam will be administered during Final Exam week. The date will be announced later in the semester, as well as the date for petitions for overload conflicts. 


\section{Attendance Policy}

Regular class attendance is required for successful completion of the course. If you are absent one day during a week, 4 points will be subtracted from your participation grade of that week; 7 points will be deducted if you are absent twice. If an absence penalty results in a negative score, a rating of zero will be recorded. Likewise, if you are absent all three days during the week, your participation will also receive a rating of zero. Work is accepted only on or before the due dates specified in the syllabus. If you are absent from class, you are responsible for making arrangements to have your work handed in on the due date, and for informing yourself of the information covered in class during the period of your absence. No other make up work will be assigned or accepted. No extra credit work is permitted. If a regularly scheduled exam is missed due to an authorized university activity, you will be given an opportunity to make up the exam, provided that an official written excuse from a coach or other university official is presented to the instructor within 10 days of the absence.

In the case of chronic illness or personal emergencies requiring prolonged or frequent absences, the student should withdraw from this course and repeat it when the circumstances allow fulfillment of course requirements.

\section{Mutual expectations}

West Virginia University is committed to social justice and academic honesty. I concur with that commitment and expect to foster a nurturing learning environment based upon open communication, mutual respect, and non-discrimination. Our University does not discriminate on the basis of sex, race, age, veteran status, disability, sexual orientation, color, national origin or religion. Any suggestions as to how to further such an environment will be appreciated and given serious consideration. The class will be conducted in accordance with the University's policies and procedures as contained in the WVU Student Handbook (The Mountie), which are expected to apply throughout the course.

If you are a person with a disability and anticipate needing any type of accommodation in order to participate in this class, please advise me and make appropriate arrangements with Disability Services (293-6700). 
Syllabus

Dates

Lesson

Assignment Due

Jan. 10 Introducción al curso

12-19 CAPÍTULO PRELIMINAR

Para empezar

[Jan. 17 Martin Luther King's birthday Recess-NO CLASS]

21-

CAPÍTULO 1

Feb 9 Perspectivas: Percepciones e impresiones

Ensayo \#1, pág. 36

QUIZ \#1

11 EXAMEN CAPÍTULOS Para empezar \& 1

14-28 Feb CAPÍTULO 2

Conexiones: ¿Qué importancia tienen nuestras

Raices?

QUIZ \#2

ENSAYO \#1 DUE

Mar. 1- CAPÍTULO 3

15 Relaciones sentimentales: ¿Cómo influyen en nuestra vida los demás?

Ensayo \#2, pág. 86

QUIZ \#3

17

EXAMEN CAPÍTULOS $2 \& 3$

Mar. 20 - CAPÍTULO 4

Apr. 10 El trabajo y el ocio: ¿Cómo se relaja usted?

QUIZ \#4

ENSAYO \#2 DUE

12 EXAMEN CAPÍTULO 4

14-28 CAPÍTULO 6

El nuevo milenio: ¿Qué nos espera en el futuro?

[Mar. 25- SPRING BREAK RECESS - NO CLASS]

Apr. 2

[Apr. 21 EASTERN RECESS - NO CLASS] 


\section{Class Participation Grading Criteria}

\section{$\underline{\text { Description }}$}

\section{$\underline{\text { Rating }}$}

During the past week, this student...

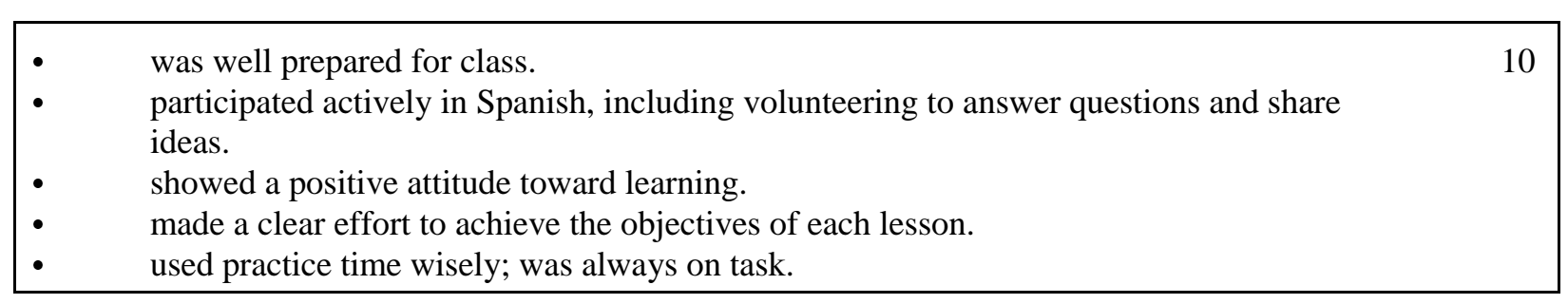

- $\quad$ was well prepared for class.

- $\quad$ participated in Spanish, although sometimes passively.

- $\quad$ showed a positive attitude toward learning.

- $\quad$ made an effort to achieve lesson objectives, although there is room for improvement.

- $\quad$ stayed on task and used practice time wisely.

- $\quad$ was somewhat prepared for class.
showed more passive than active participation in class.
had a less-than-positive attitude toward learning.
made a minimal effort toward achieving lesson objectives; there is significant room for
improvement.
tended to stray from the task at hand; could make better use of practice time

\begin{tabular}{lll|}
\hline$-\quad$ & was not well prepared for class. \\
- & was a passive or non-participant in class activities. \\
showed a negative attitude toward learning. \\
made little to no effort toward achieving lesson objectives; immediate improvement is \\
necessary.
\end{tabular}
- $\quad$ was absent all three days; thus participation is unratable.
- $\quad$ behaved in a disrespectful, distracting, or otherwise unacceptable manner (sleeping in class, reading the newspaper, leaving the room frequently or for lengthy periods of time, etc.).
- made it difficult for others in the class to learn.

\section{Penalty for absences}

Because you can only participate when you are in class, the above rating can only reflect your performance on the days when you are in attendance. From this score, 4 points will be subtracted if you have been absent one day during the week; 7 points will be deducted if you have been absent twice. If an absence penalty results in a negative score, a rating of zero will be recorded. Likewise, if you are absent all three days during the week, your participation will also receive a rating of zero. 


\section{Grading Criteria for Compositions}

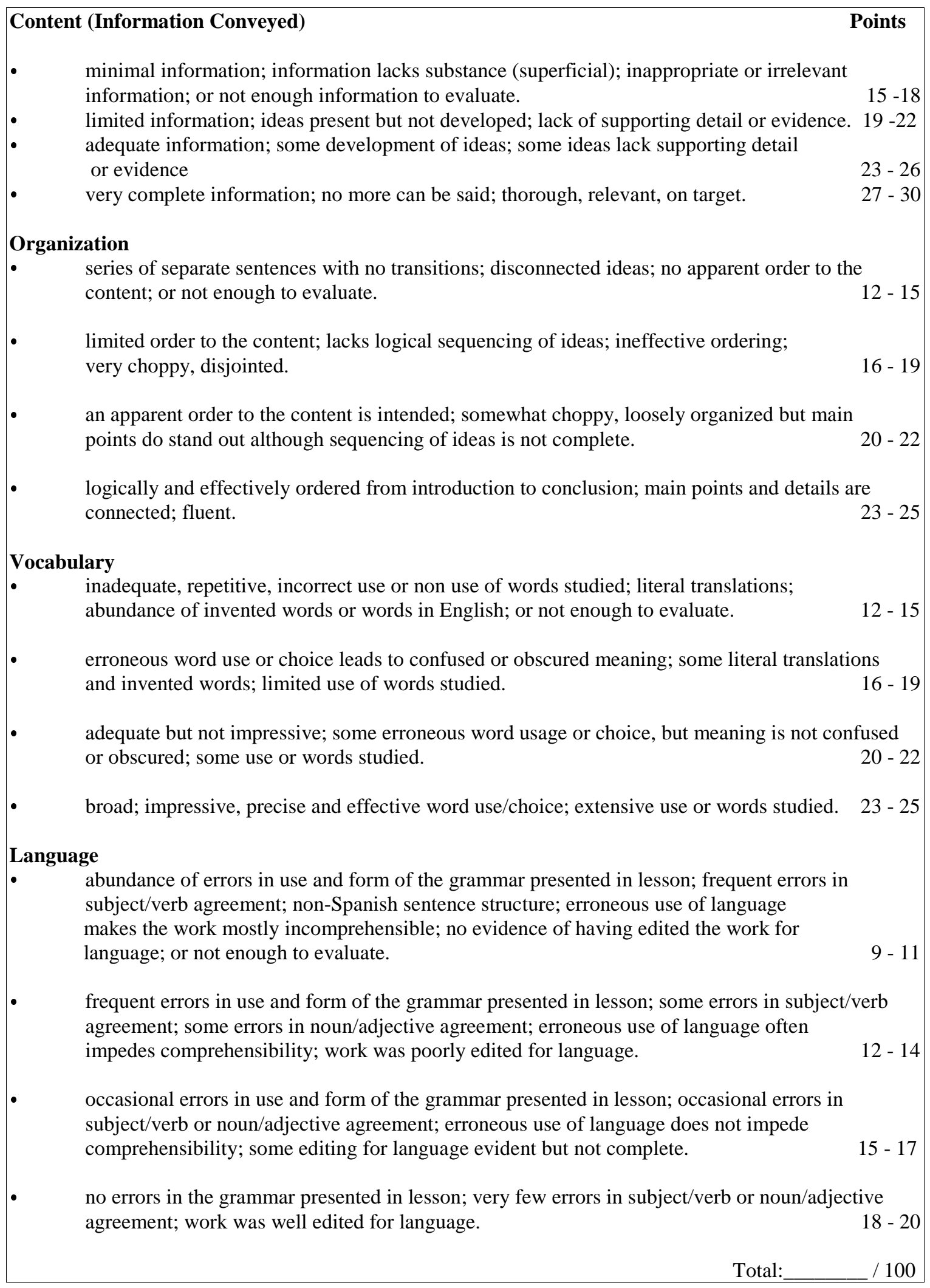




\section{Grading Criteria for Presentations}

Nombre:

Clase:

Nota: $\quad / 50$

Fecha:

Examen:

Comentarios:

\section{Comprehensibility}

1. Completely comprehensible to native speakers of Spanish.

2. Mostly comprehensible but with some errors, sometimes slow and simple.

3. Frequent errors in use of language sometimes impede

4. Mostly incomprehensible to native speakers of Spanish.

\section{Content}

1. Well developed ideas, clear, to the point. 12

2. Ideas mostly well developed, fairly clear and relevant. $\quad 10$

3. Ideas present but not well developed. 8

4. Minimal and/or irrelevant information. 5

\section{Vocabulary}

1. Rich and extensive vocabulary; very accurate usage.

2. Occasionally lacks basic words; generally adequate for situation.

3. Mostly inaccurate or inadequate.

\section{Fluency}

1. Speech generally natural and continuous; no unnatural pauses. 8

2. Some definite stumbling, but manages to rephrase or continue. 7

3. Speech frequently hesitant and jerky; sentences may be left uncompleted.

4. Speech halting and fragmentary; long, unnatural pauses or utterances.

\section{Pronunciation}

1. Generally good, accurate stress.

2. Rather good but with some striking non-Spanish sounds.

3. Generally poor, use of non-Spanish vowels and consonants, incorrect stress. 


\section{APPENDIX 3:}

\section{LESSON PLAN "EL CAMINO DE SANTIAGO.”}




\section{Appendix 3}

\section{LESSON PLAN "EL CAMINO DE SANTIAGO.”}

\begin{tabular}{|c|c|c|c|}
\hline $\begin{array}{c}\text { Step } \\
01\end{array}$ & Identify Subject Area & & FOREIGN LANGUAGES \\
\hline $\begin{array}{c}\text { Step } \\
02\end{array}$ & Identify Content Area & & Spanish (University Level 4) \\
\hline $\begin{array}{c}\text { Step } \\
03\end{array}$ & Select Content of Interest & & $\begin{array}{l}\text { Spanish Culture: The Way of St. } \\
\text { James. }\end{array}$ \\
\hline \multirow[t]{3}{*}{$\begin{array}{c}\text { Step } \\
04\end{array}$} & Identify/Determine Objectives & 4.1 & $\begin{array}{c}\text { To introduce students to one of the } \\
\text { most important events in Spain: } \\
\text { The Way of St. James. Identify } \\
\text { what it is (origin...) }\end{array}$ \\
\hline & & 4.2 & $\begin{array}{l}\text { To get to know who pilgrims are, } \\
\text { and their reasons to walk the Way } \\
\text { of St. James. }\end{array}$ \\
\hline & & 4.3 & To share findings with the class. \\
\hline \multirow[t]{3}{*}{$\begin{array}{c}\text { Step } \\
05\end{array}$} & Determine Learner Outcomes & 5.1 & $\begin{array}{l}\text { Learners will recognize what The } \\
\text { Way of St. James is. }\end{array}$ \\
\hline & & 5.2 & $\begin{array}{l}\text { Learners will identify pilgrims' } \\
\text { most relevant features and } \\
\text { determine some of their reasons to } \\
\text { walk The Way of St. James }\end{array}$ \\
\hline & & 5.3 & $\begin{array}{l}\text { Learners will improve their reading } \\
\text { and speaking skills. They will be } \\
\text { able to gather and share information } \\
\text { with others...in the target language, } \\
\text { of course }-;\end{array}$ \\
\hline \multirow[t]{3}{*}{$\begin{array}{c}\text { Step } \\
06\end{array}$} & Develop Learning Activities & 6.1 & $\begin{array}{l}\text { BRAINSTORMING ACTIVITY } \\
\text { (Pre-activity) }\end{array}$ \\
\hline & & & \begin{tabular}{c|c} 
a. & PICTURES: In order to \\
provide the students with the \\
right context they will be \\
working with later on in class, \\
I will show them some pictures \\
(Santiago de Compostela's \\
cathedral, Santiago's grave, a \\
pilgrim and a shell -symbol of \\
The Way of St.James-) \\
\end{tabular} \\
\hline & & & $\begin{array}{l}\text { The objective of the pictures is } \\
\text { to make students find the } \\
\text { connection existing among } \\
\text { them and establish the starting } \\
\text { point of the main activity in } \\
\text { that class. }\end{array}$ \\
\hline
\end{tabular}




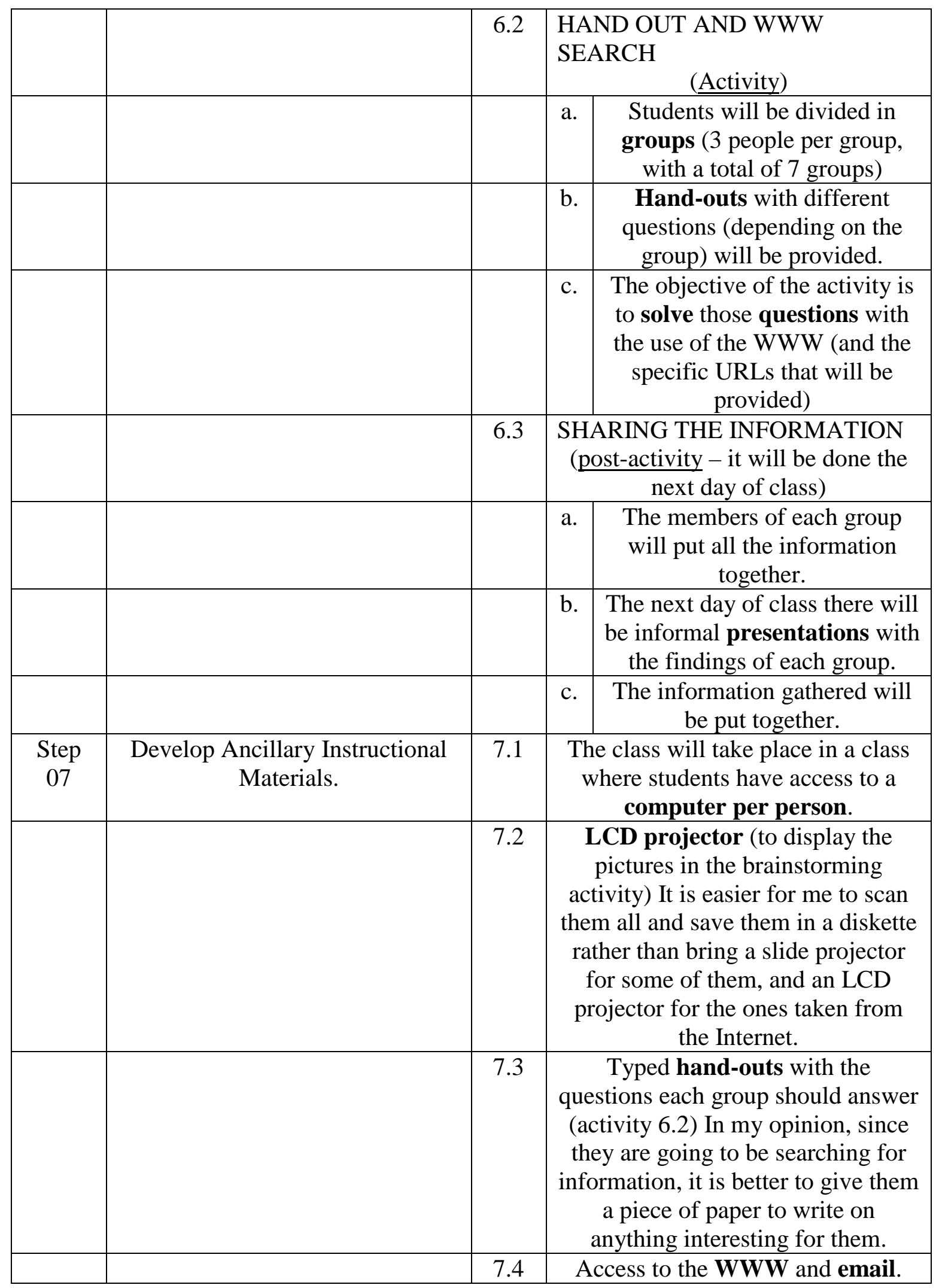




\section{Nuria Gago Olmos \\ Español 4}

\section{ACTIVIDAD EL CAMINO DE SANTIAGO...}

Como ya habéis visto, en la clase de hoy vamos a estudiar una de las fiestas más importantes de España. Esta actividad tiene como objetivo el comprender los puntos principales de lo que se conoce como "El Camino de Santiago." Este "camino" comienza en el sur de Francia, recorre el norte de España y termina en la costa noroeste de este país, en una ciudad que se llama SANTIAGO DE COMPOSTELA, que está situada en la región de GALICIA.

Utilizando las siguientes direcciones de Internet (o cuaquier otra que vosotros encontréis), responded a las siguientes preguntas:

\section{URLs:}

WwW.xacobeo.es

WwW.castillayleon.com

\section{PREGUNTAS:}

1. ¿Cuál es el símbolo del Camino de Santiago?

2. ¿Qué es el "botafumeiro"?

3. ¿Qué estaba pasando en España durante los años 800-1492? ¿Creeis que la situación de ese momento de España influyó para que la iglesia católica fomentara las peregrinaciones a Santiago de Compostela? ¿Por qué?*

4. Nombrad y descrid tres rutas que toman (to take, to follow) los peregrinos para hacer el Camino de Santiago.

5. ¿Qué tres medios de transporte usa la gente para recorrer (to 'walk') el Camino de Santiago?

6. Buscad información en las URLs que tenéis, comparad la forma de vestir que tenían los peregrinos antiguos y los de hoy en día (nowadays' pilgrims). Escribir una lista de las características de cada uno (peregrino tradicional Vs. peregrino moderno) y estudiad las cosas diferentes y las comunes (respecto a la ropa (:)).

*Extra grade question (;) 


\section{APPENDIX 4:}

HANDOUT \#1 “COMPOSICION: PROCESO Y SINTESIS.” 


\section{Appendix 4}

Nuria Gago

Viernes, 28 de Enero 2000

Composición: Proceso y Síntesis

Español 4

Composición: Proceso y Síntesis is a program created to help Spanish students to improve their writing skills. It basically focuses on writing as a process... which means that it will help you to develop and organize the ideas that you will come up with, when writing the drafts of your compositions.

This program will also help you out when having to deal with those little "differences" between Spanish and English, such as accents ("ó"), new letters ("ñn"), new symbols (" $i ")$, verbs (the way we should be conjugated), and/or any other grammatical feature that might give you a hard time. It also includes a thesaurus (synonym-antonym dictionary) just in case you want to use new words in your composition.

...But these are only some of the features of this program...In today's class, we will get to know more about Composición: Proceso y Síntesis, its structure, and all the things we can do with it. You will read about the particular features of the program, but at the same time, finding the answer to my questions, you will learn (hands-on) how to take advantage from this "tool."

\section{GENERAL STRUCTURE AND ORGANIZATION.}

One of the first things I want you to do is to become familiar with the structure and organization of Composición: Proceso y Síntesis, and the functions of the menu items that you will find there.

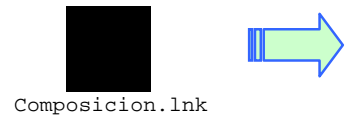

To open the program, all you have to do is double click on an icon that you will find in your desktop, which will look like this one.

Now, you should be seeing a window like the one below:

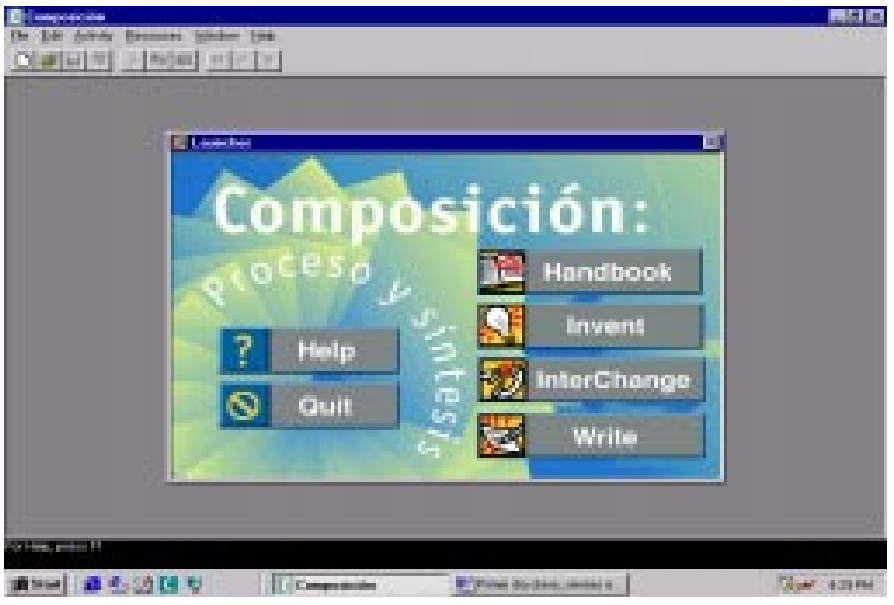


In the picture above, we can see the two main structures that are considered as the back bone of the program: The Launcher and the one containing the Primary toolbar. You can close the "launcher" (the window inside), and have Composición: Proceso y Síntesis running. But if you try to close the background one (by clicking on the " $\mathrm{x}$ " which is on the right-top part) you will just close the program itself.

\& Part 1: The PRIMARY TOOLBAR: What can we do with it?

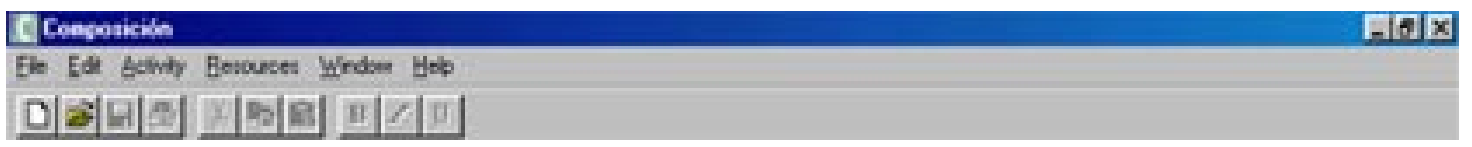

The one above, is the primary toolbar. There are many things we can do with it...but instead of me explaining you, this time we will do the other way around $\odot$;...Take a look at its "menu items" (e.g. File, Edit, Activity, Help, etc) and answer the following questions (in a new page that you will hand to me at the end of the class...by the way, don't forget to write your name (:)):

1. We all know that typing in Spanish can be rather painful if we don't have a keyboard with the Spanish "special characters" ("¿", "é”, and "Ñ"). Well, Composición: Proceso y Síntesis does solve this problem...Can you find the tool bar that allows you to do that? Now that you have it please type the following words, and symbols: $\tilde{\mathbf{N}}, \tilde{\mathbf{n}}, \boldsymbol{i}$ and $\mathbf{i}$

2. One great thing, when writing (and studying) an foreign language, is having access to a good number of resources, such as dictionaries, text books...) Apparently, Composición: Proceso y Síntesis include many of the ones I have mentioned above...Click on the menu items of the primary toolbar, and see if you can ...

2.1. Give me the two first synonyms that you will find in Composición: Proceso y Síntesis to the following words:

- Soleado

- Estudiar

2.2. Give me the two first antonyms of the words:

- Cabezón (watch out with the accent!)

- Salado

2.3. Type the definition that Composición: Proceso y Síntesis gives to the following grammatical aspects:

- COMPARATIVE (Adjective)

- REFLEXIVE VERB

- SUBJUCTIVE MOOD 
2.4. How many times have you had troubles trying to figure out the way a particular tense is conjugated in Spanish? In Composición: Proceso y Síntesis, you will find a complete list of verbs and their tenses in Spanish. To make things easier, these verbs will be divided in several categories: Regular verbs (simple tenses), regular Verbs (perfect tenses), irregular verbs, and stem-changing verbs: e.g. pensar (e, ie)

Of course, there will be verbs which won't be there...In these cases, what you have to do is to try to find out in which category it should be included: -ar, -er or -ir verbs...simple or past tenses, indicative (which is the one we usually use for simple present, simple past, present perfect, future, conditional...) or subjunctive.

Actividad: Using Composición: Proceso y Síntesis, give me the right form for:

- $3^{\text {rd }}$ person plural, TENSE: preterite indicative, VERB: Hablar Answer: Ellos hablaron

- $1^{\text {st }}$ person singular, TENSE: preterite indicative, VERB: Decir

- $1^{\text {st }}$ person singular, TENSE: imperfect indicative, VERB: Dormir (o, ue)

- $3^{\text {rd }}$ person singular, TENSE: present subjuntivo, VERB: Seguir $(\mathrm{i}, \mathrm{i})$

- $2^{\text {nd }}$ person plural, TENSE: present perfect indicative, VERB: Comer

2.5. Composición: Proceso y Síntesis has been created, as we already know, to improve Spanish students' writing skills. In order to do this, it also includes a complete guide (handbook) that explains step-by-step what to do when having to write "descripciones," "argumentaciones," etc in Spanish. Don't panic when you open this section, because we will not be using it all. Just take a look at it, and skim the information that might be useful for you. In chapter 1 (La Descripción), and chapter 5 (La Argumentación) you have to take a look a vocabulario útil, and Estrategias del escritor: El tono (only for chapter 5).

Actividad: Take a look at "vocabulario útil" in chapter 1, and type the first and last adjective of the VOCABULARIO RELACIONADO CON EL CARACTER Y LA PERSONALIDAD.

\section{$\diamond$ Parte 2: The LAUNCHER:}

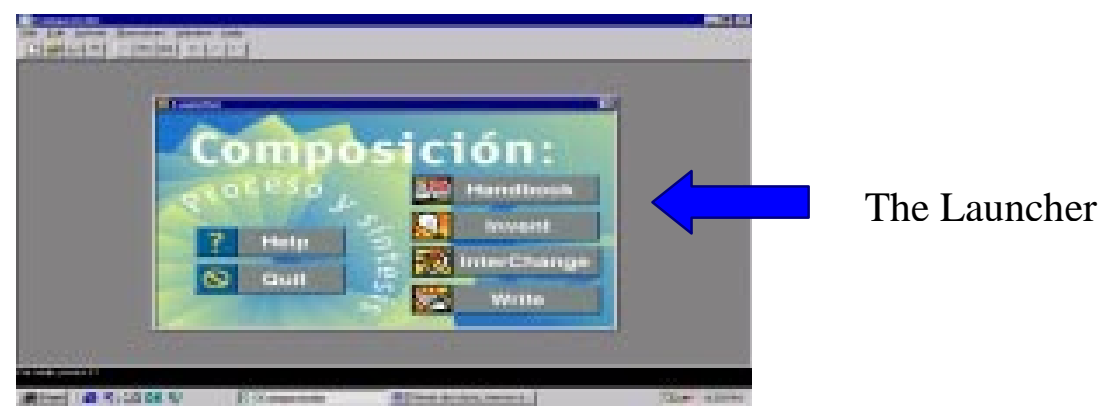


There are 6 main buttons in the Launcher. The two on your left (Help, and Quit) are very easy to use: click on "help" to look for any particular issue about Composición: Proceso y Síntesis, and click on quit" to end the program.

The 4 buttons on your right will be the ones I am more concerned with. You already know the HANDBOOK button (you have seen its contents before).

The INVENT and INTERCHANGE buttons will be studied later on. Now, I want you to focus your attention on WRITE:

WRITE is (basically) the word processor itself. This means that, many of the icons, and tools that you are going to find in it, will look like the ones in Microsoft Word, or Corel Word perfect (for example). In Composición: Proceso y Síntesis, you will be able to cut, and paste, to underline and bold words, use different fonts...

When you click on the "Write" icon, a window asking whether you want to open a new Write document, or continue with an old one (open), will pop up. Your selection, of course, will depend on what your preferences are. For the time being, we will just say that we want to open (a previous document). Now, the next window that we will be seeing will look like the following one:

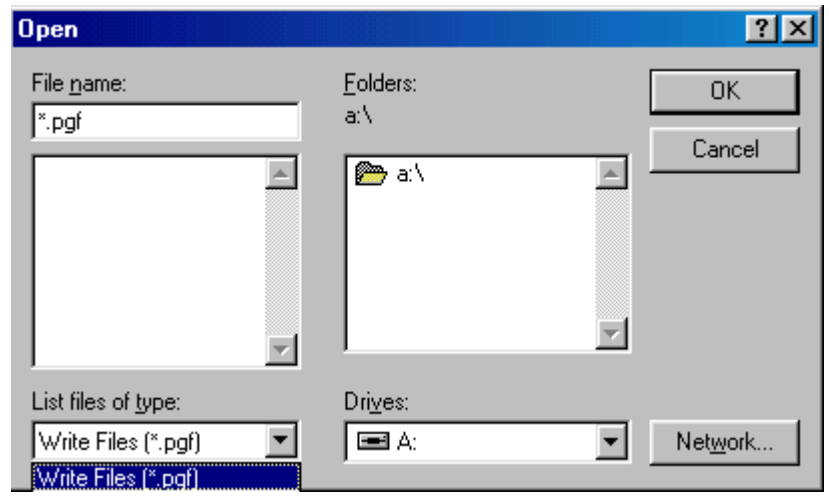

Since we are working with an existing document, we need to see where it has been saved. This is why you have to go to the "drivers" (right-bottom of the window), and open the one we need. In your case, it will be the $\mathbf{C}$ : drive $(-)$. A number of folders will appear in the "folders" window. To open those new folders, and to be able to read what they have inside, sometimes you will have to check the type of files that they are (Text files *.txt, RTF files, etc) One good thing for you to do, when saving all your files while using Composición: Proceso y Síntesis, will be to save them as RTF.

Question: It is time to look for some documents that I have placed in your C: drive. There should be two folders: one name "biografía_nuria" and the other named "Monte de las ánimas."

$\checkmark$ Open the first one (biografía) and with the information that it includes, answer the following questions: 
1. ¿Cómo se llaman mis padres?

2. ¿Cómo se llama mi hermano?

3. ¿Tengo algún animal doméstico?

4. ¿A qué lugares me gustaría viajar?

$\checkmark$ Open the second folder (El monte de las ánimas) which is also in the C: drive. You will see that it has a "weird" color...Change it to black, and use as well a new font...let's say for example...Comic Sans. Ah! make sure that it is double-spaced as well. Print out a hard copy of this document and hand it in to me with all your other answers :-)

One last question... You have learned how to open "old" documents. Now it is time for you to create your own one...Go to "write", and then create "new" document, and type anything you want in Spanish. It does not have to be too long (just 3 or 4 lines). Now that you have your text opened, why don't you check the spelling of your words? Take a look at the toolbar, and tell me where we can find this particular tool. Explain (very briefly) how it works. Don't forget handing in the answer to this last question!!

ONE PIECE OF ADVICE: Make sure that you always print out a hard copy of every draft of any of your compositions! :) 
APPENDIX 5:

HANDOUT \#2 "COMPOSICION: PROCESO Y SINTESIS.” 


\section{Appendix 5}

Nuria Gago

Lunes, 31 de enero 2000

Composición: Proceso y Síntesis (parte 2)

Español 4

$\diamond$ Last Friday you took a look at the general organization of Composición:

Proceso y Síntesis, and also learned about the main features that this program has to offer. You became familiar with tools such as the special characters, the thesaurus, handbook, spell-checker, etc. Such resources will be useful when having to work on the grammar and vocabulary of your compositions...But as you already know, those are not the only things you need to pay attention to when writing. There are other two aspects: the content and general organization of the composition, which count as much as the language and words that you use. And certainly, I will be paying a lot of attention to those (:)

One of the first things that anybody should do before writing, is actually stop to think about the topic (s)he is going to write about, the main points/aspects (s)he will talk about, how these will be included (in which order), and the target audience (in other words, who will be reading your work $(\dot{)})$. This first step is very often forgotten by many students. They just want to start doing the assignment in order to get rid of it as soon as possible... and this is the worst they can possibly do. Not spending some time to think about the general organization and content of their composition is many times, the main reason to get a bad grade.

Composición: Proceso y Síntesis has been created to help you come up with ideas that you could use as starting point for your compositions (brainstorming). The program has an icon, in the Launcher, that says: INVENT ...click on it! A window asking you whether you want to start a new invent document or open an old one will pop out. Since this is your first time using Composición: Proceso y Síntesis, you will choose new document. Now you should be seeing this in your screen:

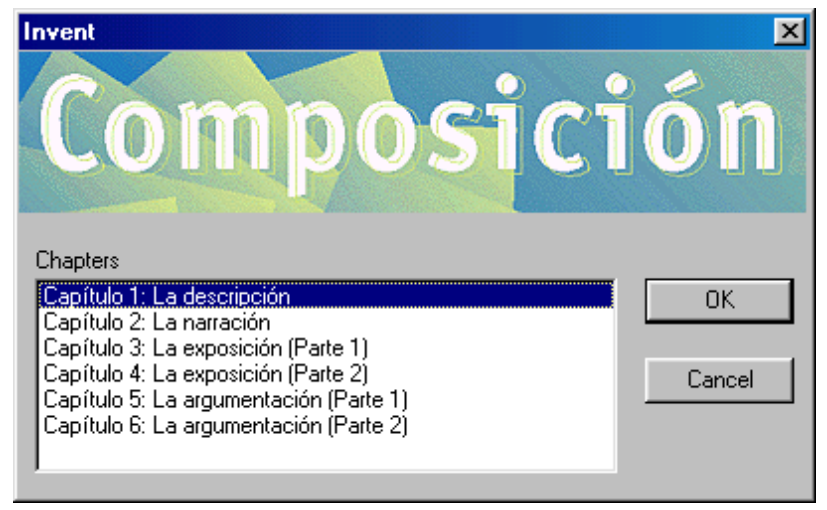

As you can see, there are several chapters in the CD-ROM...but we won't be using them all in Spanish 4, so don't panic! Today, and since it is the kind of writing you are most used to, we will be working with La descripción, so please, click on chapter 1. 
Can you see the same window that I am showing you below??

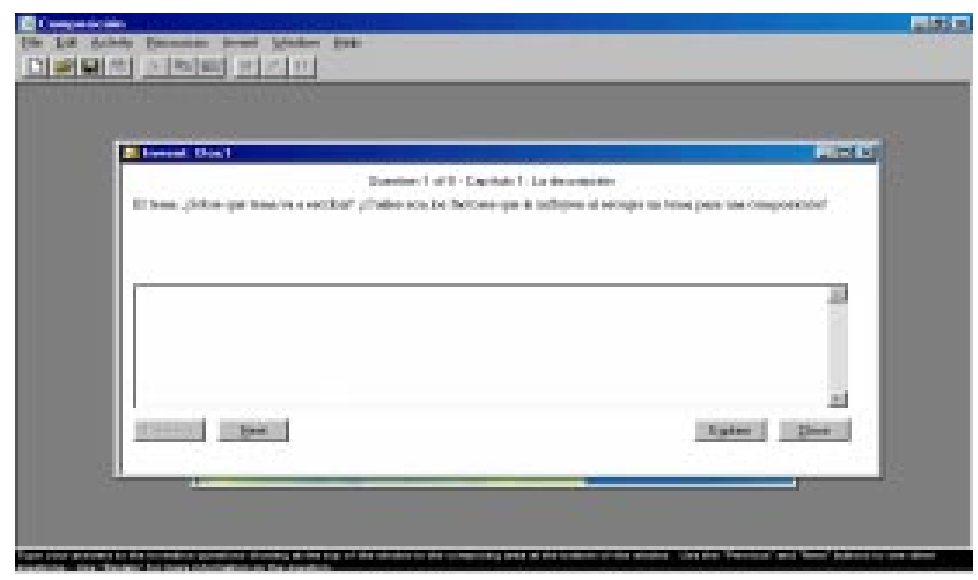

This window will ask you questions dealing with "el tema," "propósito," "los detalles," and "el lector" of the composition that you are going to write. These questions will help you to organize and focus your ideas. In case that you don't understand what you are being asked, you can use the "Explain" button (on your right, at the bottom) to get further information.

After answering these questions, and putting your thoughts all together, the next step will be the actual writing of your composition. One thing you should always remember is that no one (not even the professional writers $(\dot{)})$, is able to write anything "in one sit"... On the contrary, one good thing to do is to write whatever we can in a day, leave our work "rest a little bit," and go back to it later. It will be at this moment where we could make the appropriate changes to our mistakes. Revising is the only way to reach perfection when writing...never forget this!

通 Another very interesting feature of Composición: Proceso y Síntesis is the chat tool that it includes. It comes under the name of INTERCHANGE. It is very to use, even if this is your first time chatting! All you have to do is to click on the Interchange button (in the Launcher) and choose the conference you want to participate in. You can also create a new chat room by going to the Interchange menu item in the Primary toolbar, and then clicking on create a new conference:

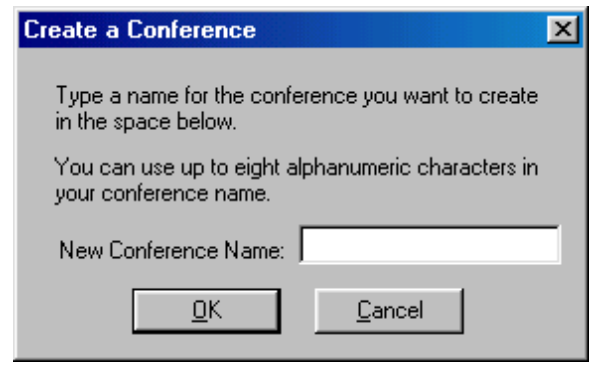

To start chatting with somebody, all you have to do is click on the channel you want to join, choose a name for the others to talk to you in the chat room, and start talking! 
APPENDIX 6:

QUESTIONNAIRE \#2 


\section{Appendix 6}

Students' name:

\section{(1) QUESTIONNAIRE \#2}

$\Delta 1$. How interested are you in developing your writing abilities in Spanish?
Very interested
Somewhat interested
Not interested

2. What do you like most about this class?

3. What do you like least about this class?

4. I feel comfortable in class ...
Always
Most of the times
Sometimes
Never

\& 5. I enjoy working with a computer (please, explain) ....

Yes __ No___ Sometimes

3 6. Before I took this class, my experience working with computers was ...

None _ V Very little __ L Little (just some word processing)

Some (email, some internet, word processing) __ _ A lot

7. What do like most about using Composición: Proceso y Síntesis? Please, explain.

8. What do you like least about using Composición: Proceso y Síntesis? Please, explain.

4 9. Can you think of any benefit(s) you get from using Composición: Proceso y Síntesis? 
10. Do you think Composición: Proceso y Síntesis is more helpful for:

$$
\begin{aligned}
& \text { Grammar __ Vocabulary ___ Content } \\
& \text { Organization ___ Other (specify) }
\end{aligned}
$$

11. Please, describe the process by which you write your composition using Composición: Proceso y Síntesis from beginning to end.

12. Is the process explained above any different from the one you used to follow before you started using this piece of software? Please explain.

13. If you have answered yes in question number 13, could you please tell me which way do you prefer to write a composition in Spanish: the one you used to follow, or the one we are using in class. Please, explain why.

14. Is there any physical constraint that bothers you when using Composición: Proceso y Síntesis? (e.g. time, setting, background noise...)

15. From a personal, affective point of view, how do you feel about using Composición: Proceso y Síntesis? Please, explain.

(Adapted from Dr. Amores' dissertation) 
APPENDIX 7:

QUESTIONNAIRE \#1 


\section{Appendix 7}

Students' name:

\section{(1) QUESTIONNAIRE \#1}

\&. How long have you been studying Spanish?

2. What is your favorite skill in Spanish? Please, check all that apply (:)

Grammar __ $\quad$ Reading __ _ Writing __ _ Speaking _

Listening __ Culture __ Other (specify)

3. From the above, which skill is easier, and which is more difficult for you? Please, explain:

4. Please, explain which is your experience writing in Spanish

5. Previous experience with computers:

None _ Some __ A lot

Please, explain

6. Computer skills. Please, check all that apply (:)

Internet (user level) ___ Email, Internet (advanced level: searching skills...)

Word Processing ___ Software Programs

Programming ___ Other (explain)

7. How do you feel when you are in front of a computer?

Anxious Insecure Confident Very Confident Other 
8. Have you ever used computers as an educational tool in any of your classes? If so, please explain when, which class it was, and what you did:

9. How do you feel about the idea of using computers in general, and a software program (Composición: Proceso y Síntesis) in this class?

I like it ___ I like it and motivates me very much ___ Anxious

I don't like it ___ I don't care __ Other (specify)

Comments:

10. What has been your first impression of Composición: Proceso y Síntesis? Please, check all that apply.

I like it

I like it, but it seems difficult to use It seems easy to use

I don't like it Other (explain)

11. Did the activity the teacher developed help you understand and become more familiar with some of the main features of Composición: Proceso y Síntesis? Please, explain.

Yes

No

12. From 1 to 10 (being 10 the highest grade possible), what score would you give to this activity? Has it been useful for you to understand the CD-ROM? Please, explain :)

$$
\begin{array}{llllllllll}
1 & 2 & 3 & 4 & 5 & 6 & 7 & 8 & 9 & 10
\end{array}
$$

13. What do you like most about Composición: Proceso y Síntesis? Please, explain.

14. What do you like least about Composición: Proceso y Síntesis? Please, explain. 
$\& 15$. What did you use before when you had to write compositions in Spanish?

(e.g. English word processors such as Microsoft word, Corel word perfect, pencil \& paper...)

$\Delta$ 16. Now that you have been introduced to Composición: Proceso y Síntesis, if you had to write a composition in Spanish, and you were told to use any tool, which one would you choose?

Traditional English word processor (e.g. Microsoft word, Corel word perfect) Pencil and a piece of paper _ Composición: Proceso y Síntesis _ 


\section{APPENDIX 8:}

TABLE 3- SECONDARY INFORMANTS' DEMOGRAPHIC DATA 


\section{Appendix 8}

\section{Table 3: Secondary participants' Demographic Data.}

\begin{tabular}{|c|c|c|c|c|c|c|c|c|}
\hline $\begin{array}{l}\text { NAME } \\
\text { (Sex) }\end{array}$ & $\begin{array}{l}\text { Agel } \\
\text { Race }\end{array}$ & $\begin{array}{l}\text { Major/ } \\
\text { Minor }\end{array}$ & Career Goals & $\begin{array}{l}\text { Home } \\
\text { Language }\end{array}$ & $\begin{array}{l}\text { Travel } \\
\text { Abroad }\end{array}$ & $\begin{array}{l}\text { Mother's } \\
\text { Education }\end{array}$ & $\begin{array}{l}\text { Father's } \\
\text { Education }\end{array}$ & $\begin{array}{c}\text { Socioeconomic } \\
\text { group }\end{array}$ \\
\hline $\begin{array}{c}\text { Jane } \\
\text { (Female) }\end{array}$ & $\begin{array}{c}17 \\
\text { (White) }\end{array}$ & N/A & $\begin{array}{c}\text { International, } \\
\text { possibly } \\
\text { humanitarian } \\
\text { work. }\end{array}$ & $\begin{array}{l}\text { English. She } \\
\text { speaks in } \\
\text { Spanish with } \\
\text { a friend. }\end{array}$ & No & College & College & Upper Middle \\
\hline $\begin{array}{c}\text { Rose } \\
\text { (Female) }\end{array}$ & $\begin{array}{c}22 \\
\text { (White) }\end{array}$ & Biology & $\begin{array}{l}\text { To become a } \\
\text { natural doctor } \\
\text { (Naturopathic } \\
\text { Dr.) with her } \\
\text { own practice. }\end{array}$ & English & $\begin{array}{l}\text { She lived in } \\
\text { Switzerland }\end{array}$ & $\begin{array}{l}\text { High } \\
\text { School }\end{array}$ & High School & Upper Middle \\
\hline $\begin{array}{c}\text { Stephanie } \\
\text { (Female) }\end{array}$ & $\begin{array}{c}19 \\
\text { (White) }\end{array}$ & None yet. & $\begin{array}{l}\text { To select a major } \\
\text { she likes and } \\
\text { continue to get a } \\
\text { Masters degree. }\end{array}$ & English & $\begin{array}{l}\text { No, but she will } \\
\text { visit Spanish on } \\
\text { the Summer. }\end{array}$ & Masters & Masters & Upper Middle \\
\hline $\begin{array}{c}\text { Carol } \\
\text { (Female) }\end{array}$ & $\begin{array}{c}22 \\
\text { (White) }\end{array}$ & $\begin{array}{l}\text { History/ } \\
\text { Political } \\
\text { Sciences }\end{array}$ & Lawyer. & $\begin{array}{c}\text { She lives } \\
\text { with uncle } \\
\text { and aunt who } \\
\text { speak } \\
\text { Spanish. }\end{array}$ & $\begin{array}{l}\text { Mexico and } \\
\text { Spain. }\end{array}$ & N/A & N/A & \\
\hline $\begin{array}{r}\text { George } \\
\text { (Male) }\end{array}$ & $\begin{array}{c}22 \\
\text { (White) }\end{array}$ & $\begin{array}{l}\text { History/Political } \\
\text { Science }\end{array}$ & $\begin{array}{c}\text { Practice law, } \\
\text { teach and maybe } \\
\text { politics. }\end{array}$ & English & No & College & College & Middle \\
\hline $\begin{array}{l}\text { John } \\
\text { (Male) }\end{array}$ & $\begin{array}{c}18 \\
\text { (White) }\end{array}$ & $\begin{array}{l}\text { Computer } \\
\text { Engineering }\end{array}$ & $\begin{array}{l}\text { Interesting well } \\
\text { paying job on } \\
\text { computers. }\end{array}$ & English & No & Doctorate. & College & Upper Middle \\
\hline
\end{tabular}


APPENDIX 9:

DEMOGRAPHIC QUESTIONNAIRE 


\section{Appendix 9}

Name:

\section{DEMOGRAPHIC QUESTIONNAIRE}

2. AGE:

SEX: Male Female

2. RACE OR ETHNOGRAPHIC BACKGROUND:

3. MAJOR: MINOR:

4. CAREER GOALS:

\$. ACADEMIC STATUS: Freshmen Senior Sophomore Junior Major requirement Elective Other

\%7. PLEASE, CIRCLE YEARS OF SPANISH TAKEN AT UNIVERSITY, AND PROVIDE GRADES OBTAINED:

Span 1 Span 2 Span 3 Span 4

8. HOME BACKGROUND (SPANISH-SPEAKING PARENT(S), AND/OR ANY OTHER OPPORTUNITIES TO SPEAK SPANISH

\%9. HAVE YOU LIVED IN A SPANISH-SPEAKING COUNTRY? STUDIED ABROAD OR IN A SPANISH-SPEAKING SCHOOL? IF SO, HOW LONG? 
10. HAVE YOU EVER TRAVELLED TO ANY SPANISH-SPEAKING COUNTRY? IF SO, PLEASE EXPLAIN

\%11. PARENT EDUCATIONAL LEVEL:

12. PARENT OCCUPATION

\&13. HOW WOULD YOU CHARACTERIZE YOUR FAMILY'S SOCIAL CLASS?

Working ___ Lower Middle __ Middle _ _ Upper Middle __ Upper __

(Adapted from Dr. Amores' dissertation) 
APPENDIX 10:

QUESTIONNAIRE \#3 


\section{Appendix 10}

\section{(i) QUESTIONNAIRE \#3}

\section{Name:}

1. What do you like most about this Spanish 4 class? Please, explain $(;)$

2. What do you like least? : Please, explain.

3. Has this class turned out to be what you expected at the beginning of the semester? Please, explain.

4. How do you like having class in Armstong Hall? If other, please, explain. A like it I don't care I don't like it It motivates me Other

5. Do you like classes better when we go there? Why?

Yes _ N No

6. Has the way you feel towards technology use in class (with educational purposes) changed since you started taking this class? Please, explain.

7. Does the way you feel have anything to do with the way I teach the class?

8. From 1 to 10 (being 10 the highest) how much do you think your writing has improved in this Spanish 4 class?

$$
\begin{array}{llllllllll}
1 & 2 & 3 & 4 & 5 & 6 & 7 & 8 & 9 & 10
\end{array}
$$


9. How much importance do you give now to the use of Composición: Proceso y Síntesis when you write in Spanish?

10. What do you like best, the way I have asked you to write the compositions, or the way you wrote them before? (Please, explain how you used to write them $(-)$ )

11. If you had to take this class again, and they told you that you would have to work with computers like we did, would you still take it? Please, explain why.

12. Do you think this project (this computer integration within the classroom) could be improved? Please, make suggestions :) 
APPENDIX 11:

ROB'S COMPOSITION. 


\section{Appendix 11}

El profesor Díaz-Plaja escríbe de los hábitos de beber de los estudiantes norteamericanos. El dice que no tienen la actitud apropriada hacia el alcohol. En su opinion los estudiantes beben para la embriaguez y el ansia de ser elegante. Según él los estudiantes norteamericanos son muy inmaduros, especialmente cuando comparados con la gente europuea. Estoy de acuerdo con el profesor Díaz-Plaja, en general él habla la verdad.

El profesor tiene razón. Muchos estudiantes americanos beben alcohol simplemente para embriagarse, mientras personas en Francie, en Italia, y en España beben alcohol con sus comdas y no por la rázon unica de embriagarse. Pienso igual que él porque he visto a las personas de que él habla. Por ejemplo estas jovenes son abundantes en fiestas y bares donde estan bebiendo pero no estan comiendo. Casi toda la bebida del alcohol toma lugar despues de la cena o durante la noche y en los fines de semana. Estas personas estan bebiendo para los rezones que el profesor Díaz-Plaja menciona en su lectura.

La cultura americana tiene un probema grande se habla alcohol. La gente americana usa alcohol como una droga para sus problemos y muchas veces con el intento de hacerse más popular. Es tal como dice el profesor Díaz-Plaja, que el alcohol es un apoyo de la sociedad. Algo se necesita hacer sobre esta situación en America. No hay una respuesta sencilla a este problema. Muchos veces personas han tratado de presentar una solución al problem, pero sus atentos no han sido efectivos. ¿Podrá la sociedad Americana cambiar sus actitud el alcohol? Cuando el profesor Diaz-Plaja dijo que este dia todavía 
estaba lejos era 1967. Sus palabras todavía son verdad hoy más de trienta años más tarde. Aun no hay cura en vista para este problema americano.

Yo diría que el profesor esta correcto la mayoría del tiempo. Aunqu eno todas estudiantes son como los describe, muchos de ellos los son. Aunque profesor Diaz-Plaja es muy perito en encontrar los problems de la sociedad Americana, no nos da soluciones. 
I have learned this at least by my experiment: that if one advances confidently in the direction of his dreams, and endeavors to live the life in which he has imagined, he will meet with a success unexpected in common hours.

- Thoreau. 